NBER WORKING PAPER SERIES

\title{
LIFECYCLE ASSET ALLOCATION STRATEGIES AND THE DISTRIBUTION OF 401(K) RETIREMENT WEALTH
}

\author{
James Poterba \\ Joshua Rauh \\ Steven Venti \\ David Wise \\ Working Paper 11974 \\ http://www.nber.org/papers/w11974
NATIONAL BUREAU OF ECONOMIC RESEARCH 1050 Massachusetts Avenue
Cambridge, MA 02138
January 2006

We are grateful to Tonja Bowen for outstanding research assistance, to John Campbell, to Luis Viceira, and Robert Willis for helpful comments, to Morningstar for providing us with mutual fund data, and to the National Institute on Aging (grants P01 AG05842 and P30 AG12810) for research support. The views expressed herein are those of the author(s) and do not necessarily reflect the views of the National Bureau of Economic Research.

(C2006 by James Poterba, Joshua Rauh, Steven Venti and David Wise. All rights reserved. Short sections of text, not to exceed two paragraphs, may be quoted without explicit permission provided that full credit, including (C) notice, is given to the source. 
Lifecycle Asset Allocation Strategies and the Distribution of 401(k) Retirement Wealth

James Poterba, Joshua Rauh, Steven Venti and David Wise

NBER Working Paper No. 11974

January 2006

JEL No. J14, J32, G11, G23, H24

\begin{abstract}
This paper examines how different asset allocation strategies over the course of a worker's career affect the distribution of retirement wealth and the expected utility of wealth at retirement. It considers both rules that allocate a constant portfolio fraction to various assets at all ages, as well as "lifecycle" rules that vary the mix of portfolio assets as the worker ages. The analysis simulates retirement wealth using asset returns that are drawn from the historical return distribution. The results suggest that the distribution of retirement wealth associated with typical lifecycle investment strategies is similar to that from age-invariant asset allocation strategies that set the equity share of the portfolio equal to the average equity share in the lifecycle strategies. There is substantial variation across workers with different characteristics in the expected utility from following different asset allocation strategies. The expected utility associated with different $401(\mathrm{k})$ asset allocation strategies, and the ranking of these strategies, is very sensitive to three parameters: the expected return on corporate stock, the worker's relative risk aversion, and the amount of non-401(k) wealth that the worker will have available at retirement. At modest levels of risk aversion, or in the presence of substantial non-401(k) wealth at retirement, the historical pattern of stock and bond returns implies that the expected utility of an all-stock investment allocation rule is greater than that from any of the more conservative strategies. Higher risk aversion or lower expected returns on stocks raise the expected utility of following lifecycle strategies or other strategies that reduce equity exposure throughout the lifetime.
\end{abstract}

James Poterba

Department of Economics

MIT, E52-350

50 Memorial Drive

Cambridge, MA 02142-1347

and NBER

poterba@mit.edu

David Wise

National Bureau of Economic Research

1050 Massachusetts Avenue

Cambridge, MA 02138-5398

and Harvard University

dwise72037@aol.com
Joshua Rauh

Graduate School of Business

University of Chicago

5807 S. Woodlawn Avenue

Chicago, IL 60637

and NBER

irauh@gsb.uchicago.edu

Steven Venti

Department of Economics

6106 Rockefeller Center

Dartmouth College

Hanover, NH 03755

and NBER

$\underline{\text { steven.f.venti@dartmouth.edu }}$ 
The growing importance of defined contribution pension arrangements, such as 401(k) plans, is shifting the responsibility for managing retirement assets from the professional money managers who oversee defined benefit plan investments to individual participants in defined contribution plans. Retirement savers face the challenge of deciding how to allocate their retirement portfolios across broad asset classes and across many different financial products. Asset allocation decisions have important consequences for retirement wealth accumulation. Some policy analysts have voiced concerns that individual participants in defined contribution plans may not fully understand the risks associated with various investment options, and that they may consequently be exposed to greater risks of retirement income shortfall in defined contribution plans than in defined benefit plans.

Quantifying the risk associated with defined contribution pension plans, and examining how individual choices affect this risk, is an active topic of research. Samwick and Skinner (2004) compare the risks associated with defined benefit and defined contribution plans for workers with a set of stylized wage and employment trajectories. Many other studies have examined the risk of different investment strategies in the context of lifetime saving programs that resemble defined contribution plans. Campbell and Viceira (2002) and Cocco, Gomes, and Maenhout (2005) explore the optimal asset allocation between stocks and bonds for lifecycle savers. Shiller (2005) tabulates the distribution of possible terminal wealth values when investors follow age-dependent asset allocation rules in a saving program that he models on a defined contribution Social Security system. Poterba, Rauh, Venti, and Wise (2005), hereafter PRVW (2005), examine how different portfolio allocation strategies over the lifecycle affect retirement wealth.

Previous findings about the level of retirement wealth associated with defined contribution saving programs, and about the risk of such wealth, are very sensitive to assumptions about the expected return on corporate stock. Stocks have offered substantially higher average returns than bonds over the eighty year sample that is often used to calibrate the return distributions. PRVW (2005) find that this has an important effect on the distribution of retirement wealth for alternative asset allocation rules. Greater exposure to stocks leads to a higher average retirement account balance. 
For a risk neutral retirement saver facing the historical return distribution, and choosing a fraction between zero and one hundred percent of her portfolio to allocate to stocks, this suggests that allocating the entire portfolio to stocks is optimal. As the risk aversion of a retirement saver increases, the optimal share of the retirement portfolio that is held in stocks declines.

Many commentators have raised questions about whether defined contribution plan participants are informed enough to make decisions about asset allocation and other dimensions of their retirement saving plan. Some plan sponsors have begun to offer participants investment options that permit them to avoid investment decision-making. One such innovation in the financial services marketplace is the "lifecycle fund" that automatically varies the share of the saver's portfolio that is held in stocks and in bonds as a function of the saver's age or years until retirement. These funds are one of the most rapidly growing financial products of the last decade. They offer investors the opportunity to exploit time-varying investment rules, typically reducing equity exposure as retirement approaches, without the need to make active investment management choices. In this paper, we consider the effect of such lifecycle investment strategies on the distribution of retirement wealth.

This paper extends previous research in two directions. First, we consider both the distribution of retirement assets and the expected utility of reaching retirement with a given asset stock. In contrast, a number of earlier studies focus only on the distribution of account balances, which does not capture the potential cost of an investment strategy with a high mean retirement balance but a small probability of a very poor outcome. We parameterize a utility-of-retirement wealth function as a power function of retirement wealth, and recognize that wealth held outside the saver's defined contribution plan can have an important effect on utility at retirement. Second, we use actual Social Security earnings histories to model household contribution flows to defined contribution plans. Several earlier studies have used simple stochastic processes to model labor income flows, or have assumed that labor income follows a stylized path over the lifecycle. Our results better capture the wide degree of heterogeneity in household earnings experiences. 
The paper is divided into five sections. The first summarizes theoretical research on the optimal pattern of age-related asset allocation. It then describes the lifecycle funds that have become increasingly popular in the retirement plan market. Section two describes the algorithm that we use to simulate the distribution of retirement plan assets under different asset allocation rules during the accumulation period. This discussion draws heavily on PRVW (2005). Section three describes our strategy for calibrating the simulation model, for selecting the sample of households for analysis, and for assigning distributions of returns to each of the assets in our study. The fourth section presents the various lifecycle asset allocation rules that we consider, including some that involve age-independent asset allocation rules. It then reports our central findings about the distribution of retirement account balances under these different rules as well as the expected lifetime utility at retirement under various rules. There is a brief conclusion.

\section{Optimal Age-Dependent Asset Allocation Rules and the Rise of Lifecycle Funds}

Financial economists have a long tradition of studying how a rational, risk-averse, long-lived consumer would choose to allocate her portfolio between risky and riskless assets at different ages. Samuelson (1969), one of the first formal analyses, challenges the conventional wisdom that an investor with a long horizon should invest a larger fraction of her portfolio in risky assets because she has an opportunity to average returns over a longer period. This result is related to the earlier, more general observation by Samuelson (1963) that taking repeated identical uncorrelated risks augments the risk of the final outcome, rather than reducing it. In the context of the lifecycle portfolio selection problem, when returns on the risky asset are serially uncorrelated and there is no labor income, a rational investor should hold the same fraction of her portfolio in risky assets at all ages. This analytical result runs counter to the suggestion of many financial advisors, who suggest that investors

reduce their equity exposure as they approach retirement. Merton (1969) derives similar results in the context of a lifetime dynamic optimization framework. 
Perhaps in part because this result is inconsistent with much financial practice, subsequent research has tried to uncover reasons why an investor might choose to reduce her equity exposure as she ages. Bodie, Merton, and Samuelson (1988) argue that younger investors have greater flexibility in their subsequent labor supply decisions, and that they should consequently be more tolerant of risk. They suggest that younger investors may rationally choose to hold a higher fraction of their portfolio in stock than older investors. Gollier (2001) and Gollier and Zeckhauser (2002) derive the conditions under which the option to rebalance a portfolio in the future affects portfolio choice. Their results suggest that under specific assumptions about the structure of utility functions, the optimal portfolio share devoted to equity will decline with age. Campbell et al. (2001), and Campbell and Viceira (2002) develop numerical solutions to dynamic models which can be used to study optimal portfolio structure over the lifecycle if shocks to labor income follow specific stochastic processes and investors have power utility. Cocco, Gomes, and Maenhout (2005) solve such a model in the presence of nontradable labor income and borrowing constraints. They find that a lifecycle investment strategy that reduces the household's equity exposure as it ages may be optimal depending on the shape of the labor income profile.

The empirical evidence on age-specific patterns in household asset allocation suggests at best weak reductions in equity exposure as households age. Gomes and Michaelides (2005) survey recent research on the correspondence between theoretical models of lifecycle asset allocation and empirical evidence on actual investment patterns. Ameriks and Zeldes (2004) and Poterba and Samwick (2001) present empirical evidence on how portfolio shares for stocks, bonds, and other assets vary over the lifecycle. The general conclusion is that equity shares decline very little at older ages, although Ameriks and Zeldes (2004) find some evidence that some households cash out their equity holdings when they reach retirement or annuitize their accumulated holdings in defined contribution accounts.

To cater to the perceived desire of investors to reduce their equity exposure as they age, and to help investors overcome the problems of inertia in retirement asset allocation that are documented by Samuelson and Zeckhauser (1988), several financial institutions have created lifecycle funds. These 
funds are usually designed for an investor with a target retirement date. Lifecycle funds were available from Fidelity Investments as early as 1988, and there were at least 250 target-year lifecycle funds in the mutual fund marketplace in 2005. Several major mutual fund families now offer a sequence of different funds targeted to investors with different retirement dates. In some cases the lifecycle fund is a "fund of funds" that invests in a mix of other mutual funds, while in other cases the fund manager holds a specific pool of assets and alters the asset mix as the fund ages.

Figure 1 shows the rapid growth in lifecycle fund assets during the last eleven years. The figure indicates that lifecycle funds held $\$ 5.5$ billion in March 2000, and that their assets had grown to $\$ 47.1$ billion by 2005 . Many of these funds are offered in 401(k) plans. Marquez (2005) reports that Hewitt Associates estimates that $38 \%$ of all 401(k) plans offer lifecycle funds. At a time when Clements (2005) reports that the proliferation of investment options 401(k) plans has come under fire, lifecycle funds offer a way to combine both stock and fixed income options into a single fund, and to offer investors a time-varying asset allocation mix. Lifecycle funds are sometimes suggested as a natural choice for the default investment option in automatic enrollment 401(k) programs.

The lifecycle funds offered at different fund families follow different age-phased asset allocation rules. Table 1 reports summary information on the lifecycle funds offered at leading mutual fund companies, which we define as the set of mutual fund companies tracked by Morningstar. The table shows the average mix of stocks and bonds currently held by funds targeting different retirement years. None of the funds publish the specific asset allocation rule that they will follow going forward as retirement dates draw nearer, but many fund prospectuses indicate the mix of various asset categories that will be held for an investor at specific ages. We have interpolated between ages, when necessary, to estimate the asset mix at a standardized set of ages.

The table also shows the net asset holdings and weighted average expense ratios of funds with different retirement years. The expenses paid by investors in these funds, which typically range between 60 and 80 basis points per year, are substantially larger than what could be paid if an investor selected mutual funds from a company offering no-load index funds with low expense ratios and then 
rebalanced among them over time. For example, equity index funds, government bond index funds and money market mutual funds can be obtained from Fidelity or Vanguard with no load fees and expense ratios of 10 to 20 basis points. However, if investors find it difficult to conduct such rebalancing on their own, or suffer from psychological biases that would lead them to neglect planned rebalancing, they might be willing to pay the additional expenses associated with target-year lifecycle funds in which the rebalancing happens automatically. A careful analysis of the expenses associated with lifecycle funds and of the services provided by these funds lies beyond the current study.

\section{Modeling Retirement Wealth Accumulation in Self-Directed Retirement Plans}

To analyze the distribution of $401(\mathrm{k})$ wealth at retirement that is induced by different asset allocation strategies, we need to model the path of plan contributions over an individual's working life and to combine these contributions with information on the potential returns to holding $401(\mathrm{k})$ assets in different investment vehicles. Rather than using information on household earnings patterns to estimate a stochastic model for the earnings process, and then using that model to simulate earnings paths for our analysis, we draw actual lifetime earnings histories from a large sample of households and carry out simulations by combining the contribution paths for various earnings histories with simulated patterns of asset returns. We focus our analysis on married couples because they are financially more homogeneous than non-married individuals, some of whom never married and others of whom have lost a spouse. About seventy percent of the individuals reaching retirement age are in married couples.

We assume that nine percent of the household's earnings are contributed to a defined contribution plan each year. We further assume that the couple begins to participate in a 401(k) plan when the husband is 28 , and that they contribute in every year in which the household has Social Security earnings until the husband is 63 . Households do not make contributions when they are unemployed or when both members of the couple are retired or otherwise not in the labor force. We 
assume that both members of the household retire when the husband is 63 if they have not done so already, and that they do not contribute to a retirement plan after that age.

To formalize our calculations, we denote a household by subscript i, and denote their $401(\mathrm{k})$ contribution at age a by $\mathrm{C}_{\mathrm{i}}(\mathrm{a})=.09 * \mathrm{E}_{\mathrm{i}}(\mathrm{a})$ for $\mathrm{E}_{\mathrm{i}}(\mathrm{a})$ the household's Social Security covered earnings at age a. The restriction to covered earnings is an important limitation that we discuss further below. We express this contribution in year 2000 dollars. To find the 401(k) balance for the couple at age 63 $(a=63)$, we need to cumulate contributions over the course of the working life, with appropriate allowance for asset returns. Let $\mathrm{R}_{\mathrm{i}}(\mathrm{a})$ denote the return earned on $401(\mathrm{k})$ assets that were held at the beginning of the year when the husband in couple i attained age a . The value of the couple's 401(k) assets when the husband is 63 is then given by:

$$
W_{i}(63)=\sum_{t=0}^{35}\left\{\prod_{j=0}^{t}\left[1+R_{i}(63-j)\right]\right\} C_{i}(63-t)
$$

$\mathrm{R}_{\mathrm{i}}(\mathrm{a})$ depends on the year-specific returns on stocks and bonds, and on the mix of stocks and bonds that the household owned when the husband was a years old. If the couple holds an all-stock portfolio, then $R_{i}(a)=R_{\text {stock }}(a)$. If the couple holds all bonds, $R_{i}(a)=R_{\text {bond }}(a)$. A mixture of the two is of course possible. If the couple invests in a lifecycle mutual fund, the asset return at age a will be $\mathrm{R}_{\text {lifecycle }}(\mathrm{a})$, which corresponds to the return on the mix of bonds and stocks that will be held by the lifecycle fund on behalf of an investor of age a.

We use simulation methods to estimate the distribution of $\mathrm{W}_{\mathrm{i}}(63)$, averaged over the households in our sample, for various asset allocation strategies. By comparing the distributions of retirement plan assets under each of these strategies, we can learn how these strategies affect retirement resources. The distribution of outcomes is of substantial interest, but it does not capture the household's valuation of different levels of retirement resources. In particular, while it can provide information on the potential frequency of low wealth outcomes, it does not provide a metric for comparing these outcomes with more favorable retirement wealth values. 
To allow for differential valuation of wealth in different states of nature, we evaluate the wealth in the 401(k) account using a utility-of-terminal wealth approach. We assume that all households have identical preferences over wealth at retirement. We drop the household subscript i, and assume that the utility of wealth is described by a constant relative risk aversion (CRRA) utility function

$$
U(W)=\frac{W^{1-\alpha}}{1-\alpha}
$$

where $\alpha$ is the household's coefficient of relative risk aversion. The utility of household wealth at retirement is likely to depend on both $401(\mathrm{k})$ and non-401(k) wealth, so we modify (2) to recognize this wealth:

$$
U\left(W_{401(k)}, W_{n o n-401(k)}\right)=\frac{\left(W_{401(k)}+W_{n o n-401(k)}\right)^{1-\alpha}}{1-\alpha}
$$

Since the effect of a change in 401(k) wealth on household utility is sensitive to the household's other wealth holdings, we consider other assets on the household balance sheet in our empirical analysis.

For a given household, each return history, denoted by h, generates a level of 401(k) wealth at age $63, \mathrm{~W}_{401(\mathrm{k}) \mathrm{h}}$, and a corresponding utility level, $U_{h}$, where

$$
U_{h}=\frac{\left(W_{401(k), h}+W_{n o n-401(k)}\right)^{1-\alpha}}{1-\alpha}
$$

We evaluate the expected utility of each portfolio strategy by the probability-weighted average of the utility outcomes associated with that strategy. These utility levels can be compared directly for a given degree of risk tolerance, and they can be translated into certainty equivalent wealth levels $(\mathrm{Z})$ by asking what certain wealth level would provide a utility level equal to the expected utility of the 
retirement wealth distribution. The certainty equivalent of an all-equity portfolio, for example, denoted by the subscript $S P 500$, is given by:

$$
Z_{S P 500}=\left[E U_{S P 500}(1-\alpha)\right]^{\frac{1}{1-\alpha}}-W_{n o n-401(k)}
$$

When a household has non-401(k) wealth, the certainty equivalent of the $401(\mathrm{k})$ wealth is the amount of $401(\mathrm{k})$ wealth that is needed, in addition to the non-401(k) wealth, to achieve a given utility level. We treat non-401(k) wealth as nonstochastic throughout our analysis.

Our approach to computing DC plan balances at retirement resembles a strategy developed in Samwick and Skinner (2004). Part of their empirical analysis considers the pension benefits that a sample of workers would earn under several stylized defined benefit and defined contribution plans. It considers the benefits experience of a sample of actual workers, with actual earnings histories, under each plan. It does not, however, explore the sensitivity of retirement wealth to alternative investment strategies.

Our approach exploits the rich cross-sectional variation in household earnings trajectories. We use a large sample of Health and Retirement Survey (HRS) households to compute contribution paths for a 401(k) plan, and we then randomly assign return histories to these contribution paths. The result is a distribution of retirement balances for each household in the HRS sample. We combine the wealth outcomes by aggregating households into three broad educational categories to report our findings, but each entry in the table below represents an average over the outcomes for many individuals. Our strategy can be thought of as drawing an HRS household at age 27 and giving it two independent draws: first a wage trajectory, which could be the actual wage trajectory for any of our sample households who have a particular education level, and then a lifetime vector of asset returns, which could be any of 200,000 draws. The return trajectory will determine the household's retirement wealth, conditional on the contribution flow. 
One of the most important shortcomings of our analysis is our restriction to top-coded Social Security earnings records, rather than actual earnings histories. The real value of the taxable maximum earnings level for Social Security has varied over time, and so has the dispersion of earnings, so the fraction of earnings that are not captured on Social Security records varies from year to year. Higher income workers have a higher likelihood of contributing to 401(k) plans, and they tend to contribute a higher share of earnings when they contribute, so the top-coding constraint is likely to bias our findings toward understating defined contribution plan accumulations. This is likely to be a particularly important concern when we present results for college-educated households, whose members' earnings are more likely to exceed the Social Security maximum than are the earnings from households with lower levels of education. There are several potential strategies for addressing topcoding problems such as those in the Social Security earnings records, and we hope to pursue them in future research.

\section{$\underline{\text { 3. Calibration of 401(k) Wealth Simulations }}$}

We select a subsample of married HRS households for analysis, construct their earnings trajectories, and measure their non-401(k) wealth at retirement. We then simulate retirement wealth based on these households' Social Security earnings records. Our sample of households is larger than that in PRVW (2005). We include all HRS couples headed by men aged 63-72 in 2000 for which Social Security earnings histories are available. Table 2 shows the effects of conditioning the sample on married couples in this age range. There are 3,833 HRS households with Social Security earnings histories. The restriction to couples eliminates approximately 44 percent of that sample, and the age restriction removes an additional 19 percent, leaving a sample of 1,400 households. The age restriction removes couples with heads between the ages of 59 and 62. Including this group would involve forecasting earnings beyond the time period of the data.

Our data restrictions make our sub-sample different from the HRS universe. This can be seen by comparing household earnings trajectories for the full HRS sample and our subsample, which we 
do in Figures 2 through 4. Figure 2 shows earnings histories for all of the households in the HRS with earnings records. Figure 3 shows earnings histories for couples in which the husband is aged 59-72, which represents essentially all couples in the HRS. Figure 3 shows earnings histories for our primary sample of 1,400 married households headed by men aged 63-72. In each figure, the sample is divided by educational attainment of the husband. Husbands are generally the primary earners in HRS households.

Two findings emerge from these figures. First, since we are focusing on couples, the total level of household earnings is higher than in the broad HRS universe for all educational levels. Second, the premium for the primary earner's education is smaller at all age ranges, but particularly in the early part of the earners' lifetime, in our sample relative to the entire HRS population. This reduction in the education premium is primarily a function of our restriction to couples. Since the education levels of members of a married couple are not perfectly correlated, by focusing on couples we pool, to some extent, individuals with different levels of educational attainment.

We consider our sample households as reaching retirement age when the husband is 63 or 64 years old, and we need to determine non-401(k) wealth at this age. Our procedure for doing this varies according to the household's age. First, we consider wealth measurement for the nearly three-quarters of the sample with a household head who was either 63 or 64 in 1996, 1998 or 2000. For these households, a breakdown of non-pension wealth is available on a consistent basis in HRS waves 3, 4, and 5. We scale all household non-401(k) asset values to the 2000 base year, so that for each household we have an estimate of what their non-401(k) wealth would have been had they turned age 63-64 in the year 2000. We implement this scaling by replacing the nominal returns on asset holdings for the two years prior to the year in which the head of household was 63 or 64, i.e. 1994-1995 for the 1996 households and 1996-1997 for the 1998 households, with nominal returns on assets in 1998 and 1999. We focus on returns in three broad categories of non-annuitized wealth: financial wealth, housing equity, and other wealth. Returns on housing equity are approximated by the growth rate of the Commerce Department's constant quality house price index. Financial wealth, both within and 
outside of retirement accounts, is assumed to grow at a composite rate based on the national average allocation of tax-deferred financial assets between stocks, bonds, and deposits, as reported in the 2001 Survey of Consumer Finances. Other household wealth, which consists largely of jewelry and vehicles, is assumed to grow with the overall price level, as measured by the CPI.

Second, we consider wealth measurement for the one-quarter of the sample that reached the ages of 63 or 64 prior to 1996. We do not use the earlier waves of the HRS because the wealth questionnaire for waves 1 and 2 was different from that for later waves. Wealth values for these HRS households are imputed for each asset class based on the median measured asset growth for households between the ages of 63 and 65, or 63 and 67, in the same educational category in later waves of the HRS.

To estimate defined benefit (DB) and defined contribution (DC) pension wealth for HRS households we use HRS pension wealth imputations, version 1.0, March 2005. This new research component of the HRS allows for more precise estimation of pension wealth than was previously possible, since it estimates imputed defined contribution wealth at all ages. For defined benefit wealth at age 63-64 we use the imputed present discounted value of pension wealth assuming retirement at age 62 and gross up by one year at the intermediate-scenario Social Security Administration rate of 3\%. For Social Security wealth (SSW) we follow the procedure from PRVW (2005), using cohort mortality tables and the Social Security Administration's intermediate-cost scenario discount rates to calculate the present discounted value of the current or projected Social Security benefits when the husband is age 63-64. We normalize the value of the wife's Social Security to be the value when the husband is aged 63-64, assuming that Social Security payments start for the wife at age 62 if they have not started already. The present value of Social Security is determined as a joint survivor annuity.

Table 3 presents summary statistics on our estimates of household balance sheets normalized to age 63-64. We report seven categories of wealth: the present discounted value (PDV) of Social Security payments, the PDV of defined benefit pensions, the PDV of other annuities, the current value of retirement accounts, the value of all other financial wealth net of debt, housing equity net of debt, 
and all other wealth. The top panel in Table 3 shows medians while the bottom panel shows means. The restriction to couples clearly raises the mean and median of the distribution. The restriction to households in the age range 63-72, with full earnings histories to age 63, lowers the wealth distribution somewhat by removing a group that has not yet begun to spend down their assets. The final sample of couples aged 63-72 has median wealth of $\$ 536,800$ and mean wealth of $\$ 783,400$. The median highschool educated household has 44 percent more total wealth than the median household with less than a high-school education, and the median college educated household has 61 percent more total wealth than the median high-school educated household. The differences in means are even more dramatic.

Table 3 also shows the distribution of several wealth aggregates. One such aggregate is annuitized wealth, which is defined as the sum of the present discounted values of Social Security, defined benefit pensions, and other annuities. We also present the sum of annuitized wealth and all other financial wealth, as well as aggregates reflecting all wealth and all wealth excluding retirement account assets. When we calibrate our simulations with households' non-401(k) wealth, we focus on two wealth components: annuitized wealth and all wealth excluding retirement account assets. We do not include retirement account assets in the calibration of non-401(k) wealth, since these emerge from our simulation. By using the observed values of these wealth components from the HRS, and treating them as non-random when we evaluate the expected utility of $401(\mathrm{k})$ retirement balances, we are implicitly assuming that changes in 401(k) wealth values do not affect other components of wealth. We hope to eventually extend our analysis to allow for correlation between the returns on assets in 401(k) accounts and the returns on other household assets.

Table 4 disaggregates the household balance sheet aggregates by education level. The table underscores the substantial differences across households both within education categories and across such categories. The difference at most percentiles between the wealth of a household that did not complete high school and one that completed college is a factor of two. These differences are of the same magnitude as the differences between the $20^{\text {th }}$ and $60^{\text {th }}$ percentiles of the distribution for a given education level. The $80^{\text {th }}$ percentile of the distribution for all three education levels that we consider 
has wealth holdings that are at close to three times as great as those of households in the $20^{\text {th }}$ percentile for the same education level.

One difficult problem in constructing the non-401(k) wealth measure that enters equation (5) concerns the role of housing equity. Venti and Wise (2001) and other studies suggest that retired households do not typically draw down their housing wealth to finance non-housing consumption. This implies that we should consider only financial resources as a source of wealth to support retirement spending, a strategy that could be justified by assuming that the utility from housing consumption is additively separable from all other consumption in the household's utility function, and that owner occupied housing generates only housing consumption. The difficulty with this approach is that it is possible that households view their housing equity as a reserve asset that can be tapped to support other consumption in the event of financial difficulty. In this case, housing equity should be combined with financial assets in calculating the household's assets outside defined contribution plans. To allow for this possibility, we present results in which we consider housing as well as other financial assets as the household's non-401(k) wealth at retirement. We treat the non401(k) components of the household balance sheet at retirement as non-stochastic, and use whatever value we calculate for the household in all of the simulations with various 401(k) balances.

We assume that the three primary assets that households may hold in their 401(k) accounts are corporate stock, nominal long-term government bonds, and inflation-indexed long-term bonds (TIPS). Calibrating the returns on these investment alternatives is a critical step in our simulation algorithm. We assume that 401(k) investors hold corporate stocks through portfolios of large capitalization U.S. stocks. We do not address the possibility of poorly diversified portfolios, for example with concentrated holdings in a single stock, as described in Munnell and Sunden (2004) and Poterba (2003). We assume that the distribution of returns on each of these asset classes is given by Ibbotson Associates' (2003) empirical distribution of returns during the 1926 to 2002 period. Large capitalization U.S. equities have an annual average real return of 9.0 percent and a standard deviation 
of 20.7 percent, whereas long-term U.S. government bonds have an annual average real return of 3.2 percent and a standard deviation of 10.0 percent.

We assume that TIPS offer a certain real return of 2 percent per year, approximately the current TIPS yield. Index bonds deliver a net-of-inflation certain return only if the investor holds the bonds to maturity, and selling the bonds before maturity exposes the investors to asset price risk. We nevertheless treat these bonds as riskless long-term investment vehicles. In our simulations, when we draw returns from the stock and bond return distributions for a given iteration, we draw returns for the same year from both distributions. This preserves the historical contemporary correlation structure between stock and bond returns in our simulations.

Several analysts suggest that recent historical equity returns may correspond to a particularly favorable time period, and that these returns should not be extrapolated to the future. The academic literature on the equity premium puzzle, summarized for example in Mehra and Prescott (2002), raises the possibility that ex post returns exceeded ex ante expected returns over this period. To allow for such a possibility, we perform some simulations in which the distribution of returns from which we draw is the actual distribution except that equity returns are reduced by 300 basis points in each year. Comparing these simulations with those in our baseline indicate the sensitivity of our findings to the future pattern of equity returns.

For each iteration of our simulation algorithm, we draw a sequence of 35 real stock and bond returns from the empirical return distribution. The draws are done with replacement and we assume that there is no serial correlation in returns. We then use this return sequence to calculate the real value of each household's retirement account balance at age 63 under the different asset allocation strategies. For each of the 1,400 households in our sample, we simulate their 401(k) balance at age 63 200,000 times. We then summarize these 200,000 outcomes either with a distribution of wealth values at retirement, or by calculating the expected utility associated with this distribution of outcomes. We found in PRVW (2005) that roughly this number of iterations was needed to obtain robust findings, particularly at lower percentiles of the retirement wealth distribution. 


\section{Discussion of Results}

We simulate nine different asset allocation strategies for the household's 401(k) account. The first three involve investing in only one asset: (i) a portfolio that is fully invested in TIPS; (ii) a portfolio that is fully invested in long-term government bonds, and (iii) a portfolio that is fully invested in corporate stock. The next two portfolios are "heuristic portfolios" that use simple rules for lifecycle asset allocation. Portfolio (iv) holds (110 - age of household head) percent of the portfolio in stock, with the remaining balance in TIPS. Portfolio (v) is similar to (iv) except that nominal government bonds replace TIPS for the component of the portfolio that is not held in equity. Both of these portfolios are rebalanced at the end of each period. The next two are lifecycle portfolios consisting of stocks and TIPS, and stocks and government bonds, respectively. The equity weight for each of these funds is computed based on the average of the age-specific allocations in the lifecycle funds at Fidelity, Vanguard, T. Rowe Price, TIAA-CREF, Principal, Barclays, and Wells Fargo. The lifecycle funds from these fund families are weighted equally in this calculation, and the resulting equity allocation is similar to that in Table 1. Portfolio (vi) invests the lifecycle fund average in equities and the balance in TIPS, while fund (vii) holds equities and nominal government bonds in the lifecycle mix. The next strategy that we consider, portfolio (viii), holds an age-independent mix of stocks and nominal government bonds. The equity share for this fund is 53 percent, which is the lifetime weighted average stock allocation in the lifecycle funds, where the weight assigned to the equity allocation in each year equals the household's $401(\mathrm{k})$ wealth at the beginning of that year, divided by the sum of beginning-of-year $401(\mathrm{k})$ wealth in all years.

The final investment strategy we consider, strategy (ix), is the "No Lose" strategy that Feldstein (2005) proposes in his analysis of individual account Social Security reforms. At each age, we calculate the share of the household's 401(k) contribution that would have to be invested in TIPS to guarantee at least the contributed amount in nominal terms at retirement age. The required TIPS investment is $\left(1+R_{T I P S}\right)^{-(63-a)}$, where $63-\mathrm{a}$ is the number of years to retirement. This strategy is 
fundamentally different from the other lifecycle strategies because it does not involve portfolio rebalancing at each age. Instead, the equity share of the portfolio depends on the historical pattern of TIPS yields, which in turn determine the amount available for stock investment in past years, and on the historical returns on equity assets.

\subsection{The Distribution of Retirement Wealth}

Table 5 shows the distribution of 401(k) balances in thousands of year 2000 dollars averaged across the 1400 households in our sample. There are two vertical panels in the table. In the left-most panel, the simulations use the historical distribution of returns. The panel on the right reduces equity returns by 300 basis points. Households are stratified by education group within each panel. The table reports the mean wealth at retirement for each strategy, as well as four points in the distribution of returns. Since our interest is the comparison of wealth outcomes across different strategies, most of our discussion below focuses on a single education group, namely households headed by someone with a high school degree but not a college degree. The relative ranking of different strategies is similar for other education groups.

The first row of Table 5 provides a point of reference for all of the subsequent calculations. It shows the certain wealth at retirement associated with strategy (i), holding only TIPS. For those with a high school degree and/or some college, this leads to a retirement balance of $\$ 162,600$. The next panels show the results from strategy (ii), holding on nominal government bonds, and strategy (iii), holding only corporate stocks. Both of these strategies, as well as all of the subsequent strategies that we consider, involve risk so we report information on the distribution of outcomes.

The second panel shows that holding only government bonds leads to a higher average retirement wealth, $\$ 192,700$, than holding TIPS. The average wealth at retirement is nearly twenty percent greater than the value with TIPS, but the median wealth of $\$ 175,000$ is less than ten percent above the TIPS outcome. Moreover, there are many outcomes with retirement wealth values below the TIPS case. The tenth percentile outcome is $\$ 106,300$, and the first percentile is $\$ 36,300$. 
When the 401(k) is invested in corporate stock, the average retirement balance is much higher than that with either TIPS or nominal government bonds: $\$ 812,000$. This value is roughly four times greater than the outcome with nominal government bonds. Because the mean return on stocks is so much higher than that on either nominal or inflation-indexed bonds, even the low outcomes are often above the mean outcomes with bonds. The $10^{\text {th }}$ percentile retirement wealth value with the all-stocks portfolio exceeds the average outcome with a nominal government bond portfolio. The first percentile outcome, however, $\$ 12,800$, is below the correspondingly low outcomes for the nominal bonds strategy.

The next two portfolios we consider, (iv) and (v), are "heuristic" lifecycle investment strategies with a mix of stocks and TIPS, or stocks and long-term nominal government bonds. In both cases the average value of retirement wealth falls between the value with an all-stock investment and that with an all-bond portfolio. When the nominal government bond share of the portfolio is (Age + 10) percent, the average value of retirement wealth using historical equity returns is $\$ 303,600$ for a household with a high school education. The proportional dispersion in the retirement wealth value is smaller than that for an all equity portfolio, and greater than that for the bond portfolio. The difference between the $90^{\text {th }}$ percentile and the $10^{\text {th }}$ percentile retirement wealth value with an all-stock strategy is 1.88 times the mean value, and the corresponding measure for the all-bond portfolio is 1.01. With the nominal bond-stock heuristic lifecycle portfolio, the $90-10$ spread is 1.16 times the mean outcome. The results for the heuristic portfolio that includes stocks and TIPS are broadly similar, although the ratio of the $90-10$ spread to the mean retirement wealth in this case is 0.90 . The first percentile outcomes with the two heuristic lifecycle portfolios are $\$ 54,300$ and $\$ 38,000$ respectively. Both are larger than first percentile outcomes with either the all-stock or all-bond portfolios.

The next two portfolios that we consider, (vi) and (vii), are the lifecycle portfolios that correspond to the average of the portfolios from various mutual fund complexes. While the agespecific equity allocation is somewhat different from the foregoing heuristic portfolios, the distribution of $401(\mathrm{k})$ wealth at retirement is similar. In particular, the mean value of retirement wealth is 
$\$ 405,300$ when we combine TIPS and stocks, and $\$ 438,200$ when we combine nominal long-term government bonds and stocks. The difference is due to TIPS offering a lower real yield than the historical average real return on nominal bonds during our sample period. The first percentile outcome when we combine TIPS with stocks is higher than that for either of the heuristic strategies, reflecting greater weight on the bond investment in this case than for those strategies.

The next portfolio strategy, (viii), is the age-invariant strategy that holds an equity share equal to the weighted average equity share in the lifecycle funds across the whole life cycle. That share is 53 percent. One of the issues that our simulations can address is how the risk and retirement wealth of this strategy compare with the corresponding measures from the lifecycle portfolios. The mean wealth from this age-invariant allocation is very similar to that from the lifecycle portfolios: $\$ 404,900$. The risk as measured by the $90-10$ spread relative to the mean is also very similar. The very low realizations from the lifecycle strategies are somewhat higher than the very low realizations from the fixed allocation, with first percentile outcomes of $\$ 35,900$ for strategy (viii) compared with $\$ 64,300$ and $\$ 48,800$ for the two lifecycle strategies. Through most of the distribution, however, it seems that the two strategies yield similar results.

The similarity of the retirement wealth distributions from the lifecycle portfolios, and from strategies that allocate a constant portfolio share to equities, is one of the central findings of our analysis. This result calls for further work to evaluate the extent to which lifecycle strategies offer unique opportunities for risk reduction relative to simpler strategies that allocate a constant fraction of portfolio assets to equities at all ages.

The last strategy we consider is the Feldstein (2005) "no lose" plan. This strategy offers a mean return that is broadly similar to the mean returns on the lifecycle strategies. The mean retirement wealth for a high school educated household is $\$ 420,300$, which is between the mean wealth values with a lifecycle fund that holds TIPS and one that holds nominal government bonds. The important difference between this strategy and the lifecycle strategies and the all-stocks and allnominal bonds strategies is found in the lower tail of the wealth outcomes. Because the "no lose" 
strategy holds TIPS, the first percentile wealth value is $\$ 113,800$, compared with values between $\$ 38,000$ and $\$ 64,300$ in the actual and heuristic lifecycle strategies.

The assumption that the equity return is drawn from its historical distribution is important for the absolute level of retirement wealth under most of the strategies that we consider, and also for the magnitude of the differences across strategies. The fourth, fifth, and sixth columns in Table 5 present results assuming that equity returns are reduced by 300 basis points. The all-stock strategy is the one that is most affected by this change. The average wealth at retirement for this strategy falls from $\$ 812,000$ to $\$ 404,800$. The tenth percentile wealth value drops from $\$ 179,900$ to $\$ 94,300$ in this case, and the first percentile value drops to $\$ 7,300$ from $\$ 12,800$. This very low outcome emphasizes the risk associated with holding stocks: a very small chance of a very poor outcome. The average retirement wealth values for the various heuristic and empirical lifecycle funds decline when we reduce the value of the mean equity return. The mean wealth value for the "no lose" strategy falls relative to the lifecycle strategies, because the no-lose strategy has relatively more equity exposure than any of the lifecycle plans.

The distribution of retirement balances shown in Table 5 is conceptually similar to the distribution reported in Shiller's (2005) analysis of personal accounts Social Security reform, although there are differences in the simulation procedure that affect the results. The most important difference is that Shiller (2005) uses data on stock and bond returns from a longer time period than we consider. This means he assumes a distribution of equity returns with a lower mean value than the one that we consider. Our results when the average return on stocks is set at 300 basis points below the historical mean in our sample are closer to those in Shiller (2005) than our results that assume that returns are drawn from the actual return distribution for 1926-2002.

\subsection{Expected Utility of Retirement Wealth}

Results like those in Table 5 do not provide any information on the household utility associated with a particular retirement wealth outcome. To address this issue, we now evaluate the 
expected utility associated with various wealth outcomes from our simulation runs, using the procedure described in (5) above.

Table 6 shows the expected utility generated by the distribution of retirement resources for each portfolio strategy using a certainty equivalent wealth measure to value the potential outcomes of the different portfolio strategies. In this table we assume that the 401(k) balance is the household's only wealth. The values in the first horizontal panel in Table 6 are based on linear utility $(\alpha=0)$ and thus are the expected values of each investment choice. These results are identical to the average household retirement wealth calculations in Table 5, since a risk-neutral household cares only about the expected value of retirement wealth. In this case the higher mean wealth of the all-stock strategy implies that it is the most preferred investment strategy. This is true both with the actual historical distribution of stock returns and with the distribution that reduces the mean return by 300 basis points. It is also true for all education groups.

The next horizontal panel in Table 6 presents results for households whose utility of retirement wealth is logarithmic. This level of risk aversion reduces the certainty equivalent value of the all-stock portfolio strategy relative to other strategies, but this strategy continues to generate the highest expected utility for all education groups. This outcome obtains when the expected stock return is set equal to its historical average, and when it is reduced by 300 basis points. The empirical lifecycle fund that combines stocks with nominal government bonds generates the highest expected utility among the four lifecycle fund strategies, and the two empirical lifecycle strategies, (vi) and (vii), yield expected utilities substantially greater than either of the heuristic lifecycle funds. The expected utility of the fixed proportions strategy continues to be close to the expected utility of the two empirical lifecycle strategies, although it now falls below both of the lifecycle strategies. This result is sensitive to the assumed rate of return on stocks; the fixed proportion strategy (viii) dominates the two empirical lifecycle strategies when equity returns are reduced by 300 basis points.

The third and fourth horizontal panels in Table 6 consider households with relative risk aversion coefficients of two and four, respectively. As risk aversion rises the lifecycle portfolios 
become more attractive relative to the all-stocks portfolio, and the "no lose" portfolio also becomes more attractive. This is illustrated most clearly by considering the bottom panel in Table 6 . The high volatility of stock returns, and the associated risk of a low retirement wealth outcome, reduces expected utility in this case relative to the earlier, less risk-averse cases. The certainty equivalent of the all-stock strategy is now $\$ 181,500$, which is still greater than the all-bond base $(\$ 140,500)$ but the disparity is far smaller than at lower risk aversion values. The various lifecycle allocation strategies dominate the all-stock strategy with a relative risk aversion of four. The certainty equivalent of the four heuristic and empirical lifecycle strategies now range from $\$ 215,500$ to $\$ 256,900$. The empirical lifecycle strategies generate higher expected utility than either of the heuristic strategies, and they also generate higher expected utility than the strategy that holds the lifetime average equity share that corresponds to these strategies, but does so at all ages. With relative risk aversion of four, the "no lose" plan also generates a higher expected utility than the all-stock strategy.

Three additional features of the results with a relative risk aversion of four warrant comment. First, when the average return on stocks is reduced by 300 basis points, the certainty equivalent of the all-stock strategy declines sharply, while the corresponding values for the lifecycle funds and the nolose strategy do not decline as much. Feldstein's (2005) "no lose" strategy is the preferred strategy in this setting, with the empirical lifecycle strategy blending stocks and TIPS taking the second rank.

Second, the "no lose" strategy becomes more attractive as the level of risk aversion increases. With a risk aversion of two, the "no-lose" plan yields an expected utility that falls below either of the empirical lifecycle allocation strategies, either with historical equity returns or with reduced average returns. In the case with relative risk aversion of four, the certainty equivalent of the "no lose" plan is roughly equal to the nominal bonds and stocks lifecycle strategy, and somewhat below that of the stocks-TIPS lifecycle strategy, when equity returns have their historical values. When equity returns are reduced by 300 basis points, the certainty equivalent of the no-lose plan exceeds that of either of the lifecycle strategies. 
Third, the expected utility associated with either heuristic lifecycle funds or empirical lifecycle funds rises relative to the expected utility of an all-stock investment strategy as risk aversion increases. For a relative risk aversion of one, the certainty equivalent of an empirical lifecycle strategy that holds stocks and government bonds is roughly two-thirds of the certainty equivalent of an all-stock strategy, and it is roughly twice the certainty equivalent of an all-bond strategy. For a relative risk aversion of four, however, the empirical lifecycle strategy's certainty equivalent is about one third greater than that of an all-stock portfolio, and sixty percent greater than an all-bond portfolio. These findings suggest that the relative attraction of lifecycle funds and other asset allocation strategies is likely to be highly dependent upon household circumstances.

Table 6 considers the certainty equivalent of different investment strategies when retirement wealth from a 401(k) plan is the only source of utility at retirement. By assuming that the household is solely dependent on 401(k) wealth, these calculations exaggerate the level of retirement income risk faced by the household. Holding constant the household's relative risk coefficient, when the household has other sources of wealth, it will behave as though it was less risk averse.

Tables 7 and 8 present results with two alternative assumptions about non-401(k) wealth at retirement. The results in Table 7 set non-401(k) wealth equal to other financial wealth in the HRS, while those in Table 8 set non-401(k) wealth equal to all other wealth, adding together both financial wealth and housing wealth. The households in both cases are less averse to holding high fractions of their wealth in stocks. For a relative risk aversion of two, for example, the certainty equivalent value of contributing to a $401(\mathrm{k})$ that is invested in the empirical lifecycle fund with stocks and TIPS is $\$ 320,400$ when households have no wealth at retirement other than their retirement wealth. This value can be found in Table 6 . When other financial wealth is combined with retirement account wealth in determining the utility of retirement wealth, the certainty equivalent of the same strategy rises to $\$ 353,000$. With housing equity added to the total, the certainty equivalent rises to $\$ 366,100$. In each case these values represent the certainty equivalent of just the $401(\mathrm{k})$ account balance. This is the amount in addition to other wealth that would be needed to generate the expected utility associated 
with the uncertain retirement wealth distribution. The average value of retirement wealth associated with this strategy is $\$ 405,300$, so the reduction in certainty equivalent value associated with the risk of unfavorable outcomes is smaller as non-401(k) wealth rises.

Allowing for non-retirement account wealth raises the attraction of stocks relative to other financial investments. In both Tables 7 and 8, for all the risk aversion parameters that we consider, the expected utility of holding an all-stock portfolio is greater than that from holding any of the other portfolios that we consider. These results underscore the importance of recognizing and calibrating non-401(k) wealth as part of the valuation process.

\section{$\underline{\text { 5. Conclusions }}$}

This paper presents evidence on the distribution of balances in 401(k)-type retirement saving accounts under various assumptions about the asset allocation strategies that investors choose. In addition to a range of age-invariant strategies, such as an all-bond and an all-stock strategy, we consider several different "lifecycle funds" that automatically alter the investor's mix of assets as he or she ages. These funds offer investors a higher portfolio allocation to stocks at the beginning of a working career than as they approach retirement. We also consider a "no lose" allocation strategy for retirement saving, in which households purchase enough riskless bonds at each age to ensure that they will have no less than their nominal contribution when they reach retirement age, and then invest the balance in corporate stock. This strategy combines a riskless floor for retirement income with some upside investment potential.

Our results suggest several conclusions about the effect of investment strategy on retirement wealth. First, the distribution of retirement wealth associated with typical lifecycle investment strategies is similar to that from age-invariant asset allocation strategies that set the equity share of the portfolio equal to the average equity share in the lifecycle strategies. Second, the expected utility associated with different $401(\mathrm{k})$ asset allocation strategies, and the ranking of these strategies, is very sensitive to three parameters: the expected return on corporate stock, the relative risk aversion of the 
investing household, and the amount of non-401(k) wealth that the household will have available at retirement. At modest levels of risk aversion, or when the household has access to substantial non401(k) wealth at retirement, the historical pattern of stock and bond returns implies that the expected utility of an all-stock investment allocation rule is greater than that from any of the more conservative strategies. When we reduce the expected return on stocks by 300 basis points relative to historical values, however, other strategies dominate the all-equity allocation for investors with high levels of relative risk aversion. The "no lose" plan yields an expected utility of wealth at retirement that is comparable to several of the lifecycle plans, but both the expected value of wealth and the expected utility level are slightly lower than the values associated with the lifecycle strategies that we consider.

Our analysis of lifecycle funds suggests a number of issues that may warrant future research. First, it is possible that lifecycle funds should be different for single individuals and for married couples. The focus in these funds so far has been on accumulating wealth for retirement, and the conceptual justification for age-phased equity exposure would be age-related variation in household risk aversion. Single individuals may have fewer opportunities to respond to an adverse economic shock than married couples, so their tolerance of equity market risk in their retirement accounts may be different from that for married couples.

Second, we have focused on only a limited set of outcome measures associated with different asset allocation strategies. While we consider various percentiles of the retirement wealth distribution, as well as the mean value of wealth at retirement, and the expected utility associated with this wealth value, other metrics may also deserve consideration. One possibility is the risk of shortfall associated with one strategy relative to another. The Feldstein (2005) "no lose" strategy eliminates the shortfall risk associated with a defined contribution investment strategy relative to investing all contributions to a defined contribution plan in a zero-yield cash account. Shortfall risk measures could be computed for a range of other strategies.

Third, our analysis has not reduced participant returns in 401(k) plans for the expense ratios associated with asset management. Actual returns are reduced by these fees, and a potentially 
important issue in the comparison of lifecycle funds and other investment vehicles is the differential in fees across these investment options. We are currently exploring the effect of introducing investment management fees to a simulation algorithm like that developed here.

Finally, our analysis has considered several stylized lifecycle funds, but it has not tried to determine the optimal age-related allocation between stocks and bonds for households like the ones we examine. Several previous studies, including Campbell and Viceira (2002), Campbell, Cocco, Gomes, and Maenhout (2001), and Cocco, Gomes and Maenhout (2005), have evaluated optimal lifecycle portfolios under stylized assumptions about labor market risk and the distribution of financial market returns. It would be useful to compare the expected utility from the optimal lifecycle fund with the expected utility either from existing lifecycle funds or from age-invariant asset allocation rules. 


\section{$\underline{\text { References }}$}

Ameriks, John, and Stephen Zeldes, 2004, "Do Household Portfolio Shares Vary with Age?," mimeo, Columbia University Graduate School of Business.

Bodie, Zvi, Robert C. Merton, and William Samuelson, 1991, "Labor Supply Flexibility and Portfolio Choice in a Lifecycle Model," Journal of Economic Dynamics and Control 16, 427-449.

Campbell, John Y. and Luis M. Viceira, 2002, Strategic Asset Allocation: Portfolio Choices for Long Term Investors (New York: Oxford University Press).

Campbell, John Y., Joao Cocco, Francisco Gomes, and Pascal Maenhout, 2001, “Investing Retirement Wealth: A Life-Cycle Model," in John Y. Campbell and Martin Feldstein (eds), Risk Aspects of Investment-Based Social Security Reform (Chicago: University of Chicago Press).

Clements, Jonathan, 2005, "Plan Paralysis: Why a Wealth of Choices in 401(k)s May Not Make Investors Rich,” Wall Street Journal May 4, page C1.

Cocco, Joao, Francisco Gomes, and Pascal Maenhout, 2005, "Consumption and Portfolio Choice over the Life Cycle," Review of Financial Studies, 18(2), 491-533.

Gomes, Francisco and Alexander Michaelides, 2005, “Optimal Life Cycle Asset Allocation: Understanding the Empirical Evidence," Journal of Finance 60, 869-904.

Feldstein, Martin, 2005, "Reducing the Risk of Investment-Based Social Security Reform,” NBER Working Paper 11084.

Gollier, Christian, 2001, The Economics of Risk and Time (Cambridge: MIT Press).

Gollier, Christian and Richard J. Zeckhauser, 2002, "Horizon Length and Portfolio Risk,” Journal of Risk and Uncertainty 24, 195-212.

Ibbotson Associates, 2003, Stocks, Bonds, Bills, and Inflation: 2003 Yearbook: Market Results for 1926-2002. (Chicago: Ibbotson Associates).

Marquez, Jessica, 2005, “Lifecycle Funds Can Help Companies Mitigate Risk and Boost Employee Savings," Workforce Management, April, 65-67. 
Mehra, Rajneesh and Edward Prescott, 2002, “The Equity Premium Puzzle in Retrospect,” in G.

Constantinides, M. Harris, and R. Stulz, eds., Handbook of Economics of Finance

(Amsterdam: North Holland).

Merton, Robert C., 1969, "Lifetime Portfolio Selection under Uncertainty: The Continuous Time Case," Review of Economics and Statistics 51, 247-257.

Munnell, Alicia and Annika Sunden, 2004, Coming Up Short: The Challenge of 401(k) Plans

(Washington: Brookings Institution).

Poterba, James, 2003, “Employer Stock and 401(k) Plans,” American Economic Review 93 (May), 398-404.

Poterba, James, Joshua Rauh, Steven Venti and David Wise, 2005, "Utility Evaluation of Risk in Retirement Savings Accounts," in David Wise (ed), Analyses in the Economics of Aging, Volume 10, University of Chicago Press.

Poterba, James, and Andrew Samwick, 2001, "Household Portfolio Allocations Over the Lifecycle," in S. Ogura, T. Tachibanaki, and D. Wise, ed., Aging Issues in the U.S. and Japan (Chicago: University of Chicago Press), 65-103.

Samuelson, Paul, 1963, "Risk and Uncertainty: the Fallacy of the Law of Large Numbers," $\underline{\text { Scientia }}$ 98, 108-113.

Samuelson, Paul, 1969, "Lifetime Portfolio Selection by Dynamic Stochastic Programming,” Review of Economics and Statistics 51, 239-246.

Samuelson, Paul, 1989, “The Judgement of Economic Science on Rational Portfolio Management: Indexing, Timing, and Long-Horizon Effects,” Journal of Portfolio Management, Fall, 3-12.

Samuelson, William, and Richard J. Zeckhauser, 1988, “Status Quo Bias in Decision Making," Journal of Risk and Uncertainty 1, 7-59.

Samwick, Andrew, and Jonathan Skinner, 2004, "How Will 401(k) Plans Affect Retirement Income?," American Economic Review 94, 329-343. 
Shiller, Robert, 2005, “The Life Cycle Personal Accounts Proposal for Social Security: A Review," NBER Working Paper 11300.

Venti, Steven F. and David A. Wise, 2001, "Aging and Housing Equity: Another Look," in David A. Wise (ed.) Analyses in the Economics of Aging, Volume 9, University of Chicago Press. 
Table 1: Target-Year Lifecycle Mutual Fund Characteristics, March 2005

\begin{tabular}{|c|c|c|c|c|c|c|c|c|}
\hline \multirow[t]{2}{*}{$\begin{array}{c}\text { Retirement } \\
\text { Year }\end{array}$} & \multirow[t]{2}{*}{$\begin{array}{c}\text { Years to } \\
\text { Retirement }\end{array}$} & \multirow[t]{2}{*}{$\begin{array}{c}\text { Net } \\
\text { Assets } \\
\text { (\$ billion) }\end{array}$} & \multirow[t]{2}{*}{$\begin{array}{c}\text { Weighted } \\
\text { Average } \\
\text { Expense } \\
\text { Ratio } \\
\end{array}$} & \multirow[t]{2}{*}{$\begin{array}{l}\text { Number } \\
\text { of Fund } \\
\text { Families }\end{array}$} & \multirow[t]{2}{*}{$\begin{array}{l}\text { Number } \\
\text { of Funds }\end{array}$} & \multicolumn{3}{|c|}{$\begin{array}{c}\text { 2005Q1 Weighted Average } \\
\text { Asset Allocation }\end{array}$} \\
\hline & & & & & & Stocks & Bonds & Cash \\
\hline 2005 & 0 & 4.1 & $0.6 \%$ & 10 & 40 & $30.0 \%$ & $42.0 \%$ & $28.0 \%$ \\
\hline 2010 & 5 & 11.2 & $0.8 \%$ & 13 & 45 & $49.4 \%$ & $35.4 \%$ & $15.3 \%$ \\
\hline 2015 & 10 & 2.9 & $0.6 \%$ & 8 & 22 & $58.2 \%$ & $35.7 \%$ & $6.1 \%$ \\
\hline 2020 & 15 & 14.5 & $0.8 \%$ & 13 & 45 & $69.7 \%$ & $24.6 \%$ & $5.7 \%$ \\
\hline 2025 & 20 & 1.9 & $0.6 \%$ & 8 & 22 & $79.2 \%$ & $17.2 \%$ & $3.6 \%$ \\
\hline 2030 & 25 & 8.3 & $0.8 \%$ & 12 & 39 & $81.7 \%$ & $13.8 \%$ & $4.5 \%$ \\
\hline 2035 & 30 & 0.6 & $0.8 \%$ & 6 & 15 & $85.2 \%$ & $10.4 \%$ & $4.4 \%$ \\
\hline 2040 & 35 & 3.3 & $0.8 \%$ & 11 & 38 & $88.0 \%$ & $8.4 \%$ & $3.5 \%$ \\
\hline
\end{tabular}

Funds used in this analysis consist of all mutual funds categorized by Morningstar as retirement or lifecycle funds which also have a target-year rebalancing feature. Net assets for these funds as of 3/31/2005 were collected from fund reports and from Morningstar.com. The number of funds differs from the number of fund families for a given retirement year because funds have multiple classes of shares and "number of funds" counts each share class as a separate fund. The weighted average expense ratio is the average expense ratio including sub-fund expenses weighted by fund net asset value. Asset allocations are also averaged with fund net asset value weighting. One fund family also offers funds with retirement years 2011, 2012, 2013, 2014, 2045, and 2050. The information on these funds is not used in constructing this table.

Table 2: Sample Composition, HRS Households

\begin{tabular}{|c|c|c|c|c|}
\hline & $\begin{array}{c}\text { All } \\
\text { Households, } \\
\text { Head 59-72 }\end{array}$ & $\begin{array}{c}\text { Households } \\
59-72 \text {, with } \\
\text { SS } \\
\text { Earnings }\end{array}$ & $\begin{array}{c}\text { Couples } \\
59-72, \\
\text { with SS } \\
\text { Earnings }\end{array}$ & $\begin{array}{c}\text { Couples } \\
63-72, \\
\text { with SS } \\
\text { Earnings }\end{array}$ \\
\hline \multicolumn{5}{|c|}{ ousehold Head Education Less Than High School } \\
\hline Survey Households & 1579 & 1086 & 540 & 374 \\
\hline Population Counterpart & 3769.3 & 2653.4 & 1324.2 & 938.3 \\
\hline \multicolumn{5}{|c|}{ Household Head High School Education and/or Some College } \\
\hline Survey Households & 2793 & 1954 & 1076 & 689 \\
\hline Population Counterpart & 7669.2 & 5453.6 & 3013.2 & 1949.3 \\
\hline \multicolumn{5}{|c|}{ Household Head at least College Degree } \\
\hline Survey Households & 1132 & 793 & 526 & 337 \\
\hline Population Counterpart & 3411.6 & 2390.6 & 1611.8 & 1013.6 \\
\hline \multicolumn{5}{|l|}{ Total } \\
\hline & & 3833 & 2142 & 1400 \\
\hline Population Counterpart & 14850.1 & 10497.6 & 5949.2 & 3901.1 \\
\hline
\end{tabular}

Source: Authors' tabulations based on the 2000 wave of the HRS and the social security earnings histories available for a sub-sample of HRS respondents. Population counterparts are calculated using the household weights provided in the HRS. 
Table 3: Summary Statistics on Household Balance Sheet at Age 63/64, HRS Households

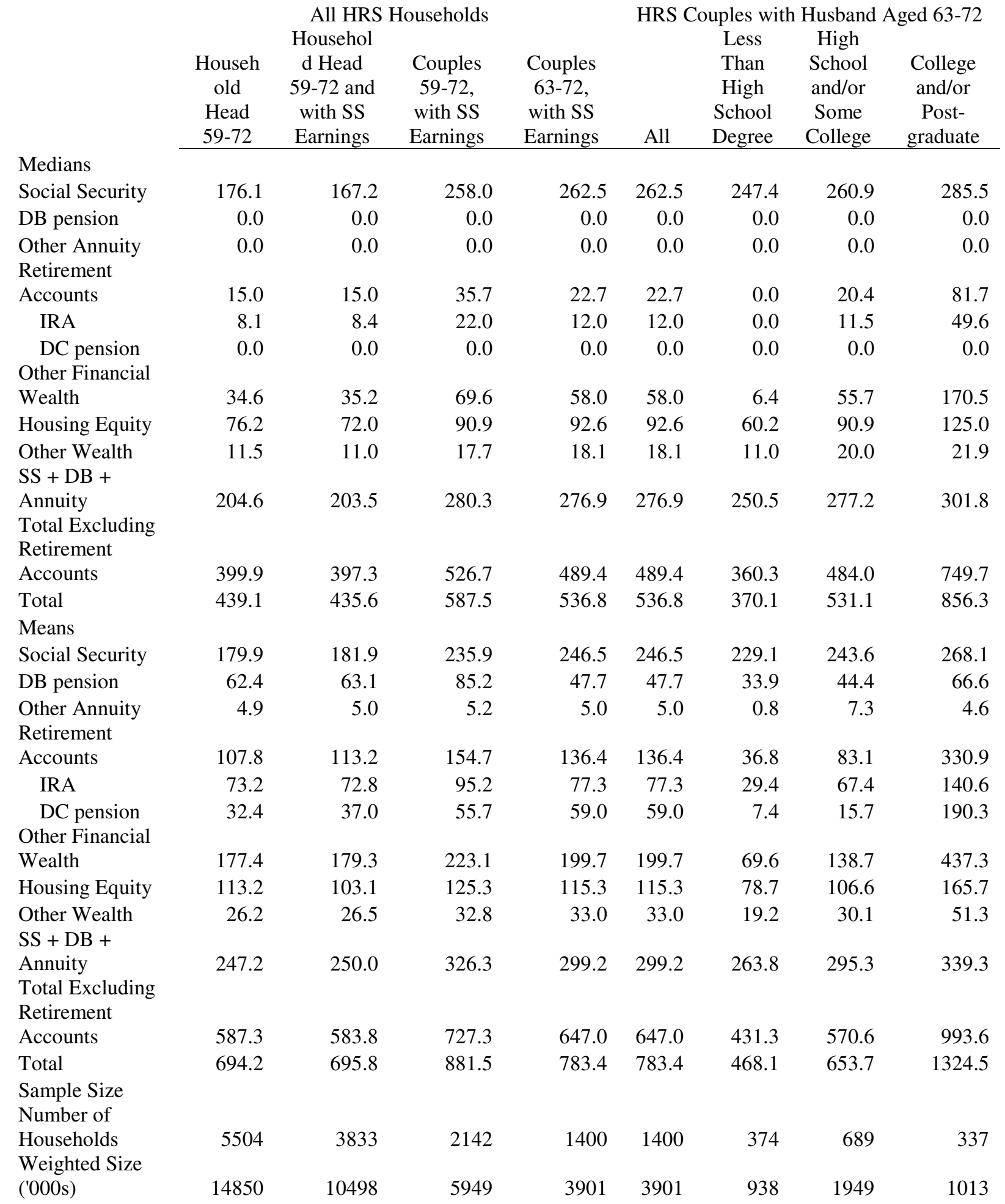

Source: Authors' tabulations based on the 2000 HRS. All entries are normalized to calendar year 2000. To estimate DB and DC pension wealth for HRS households we use the pension wealth imputations from the HRS (March 2005 version). Other financial wealth includes stocks, equity mutual funds, bonds, fixed income mutual funds, checking and saving accounts, money market mutual funds and certificates of deposit held outside of retirement accounts. Social security wealth is calculated as in PRVW (2005). 
Table 4: Distribution of Household Balance Sheet for HRS Couples with Husbands Aged 63-72, Normalized to Age 63/64 in Year 2000

\begin{tabular}{|c|c|c|c|c|}
\hline Net Worth Concept & $\begin{array}{l}\text { All } \\
\text { Education } \\
\text { Levels }\end{array}$ & $\begin{array}{l}\text { Less Than } \\
\text { High School } \\
\text { Degree }\end{array}$ & $\begin{array}{l}\text { High School } \\
\text { and/or Some } \\
\text { College }\end{array}$ & $\begin{array}{l}\text { College and/or } \\
\text { Postgraduate }\end{array}$ \\
\hline 20th percentile & & & & \\
\hline SS + DB + Annuity & 189.8 & 169.4 & 198.8 & 204.6 \\
\hline $\begin{array}{l}\text { Total Excluding Retirement } \\
\text { Accounts }\end{array}$ & 292.2 & 216.8 & 312.2 & 387.8 \\
\hline $\begin{array}{l}\text { Total } \\
\text { 40th percentile }\end{array}$ & 302.0 & 220.9 & 315.1 & 448.1 \\
\hline SS + DB + Annuity & 257.0 & 230.7 & 257.3 & 281.2 \\
\hline $\begin{array}{l}\text { Total Excluding Retirement } \\
\text { Accounts }\end{array}$ & 419.1 & 314.1 & 423.6 & 607.8 \\
\hline $\begin{array}{l}\text { Total } \\
\text { 60th percentile }\end{array}$ & 450.1 & 323.2 & 450.4 & 707.9 \\
\hline SS + DB + Annuity & 295.6 & 265.7 & 296.1 & 338.0 \\
\hline $\begin{array}{l}\text { Total Excluding Retirement } \\
\text { Accounts }\end{array}$ & 575.3 & 413.6 & 549.8 & 878.6 \\
\hline $\begin{array}{l}\text { Total } \\
\text { 80th percentile }\end{array}$ & 637.4 & 441.3 & 622.1 & 1051.1 \\
\hline SS + DB + Annuity & 362.8 & 313.7 & 354.3 & 449.3 \\
\hline $\begin{array}{l}\text { Total Excluding Retirement } \\
\text { Accounts }\end{array}$ & 830.4 & 575.4 & 745.2 & 1229.6 \\
\hline Total & 994.5 & 644.1 & 866.4 & 1598.6 \\
\hline
\end{tabular}

Source: Authors' tabulations from the 2000 HRS. DB pension wealth was calculated from the pension wealth imputations from the HRS (March 2005 version). Social security and annuity wealth were computed as in PRVW (2005). 
Table 5: Simulated Distribution of 401(k) Balances at Retirement (\$2000)

\begin{tabular}{|c|c|c|c|c|c|c|}
\hline \multirow{4}{*}{$\begin{array}{l}\text { Investment } \\
\text { Strategy/ } \\
\text { Percentile }\end{array}$} & \multicolumn{3}{|c|}{ Empirical Stock Returns } & \multicolumn{3}{|c|}{ Empirical Returns Reduced 300 Basis Points } \\
\hline & \multirow{3}{*}{$\begin{array}{l}\text { Less Than } \\
\text { High School } \\
\text { Degree }\end{array}$} & \multirow{3}{*}{$\begin{array}{l}\text { High School } \\
\text { and/or Some } \\
\text { College }\end{array}$} & \multirow{3}{*}{$\begin{array}{c}\text { College } \\
\text { and/or } \\
\text { Postgraduate }\end{array}$} & \multirow{3}{*}{$\begin{array}{l}\text { Less Than } \\
\text { High School } \\
\text { Degree }\end{array}$} & \multirow{3}{*}{$\begin{array}{l}\text { High School } \\
\text { and/or Some } \\
\text { College }\end{array}$} & \multirow{3}{*}{$\begin{array}{c}\text { College } \\
\text { and/or } \\
\text { Postgraduate }\end{array}$} \\
\hline & & & & & & \\
\hline & & & & & & \\
\hline $100 \%$ TIPS & 137.6 & 162.6 & 174.4 & 137.6 & 162.6 & 174.4 \\
\hline \multicolumn{7}{|c|}{$100 \%$ Government Bonds } \\
\hline 1 & 31.0 & 36.3 & 41.3 & 31.0 & 36.3 & 41.3 \\
\hline 10 & 90.1 & 106.3 & 115.5 & 90.1 & 106.3 & 115.5 \\
\hline 50 & 148.0 & 175.0 & 187.2 & 148.0 & 175.0 & 187.2 \\
\hline 90 & 253.2 & 300.2 & 316.2 & 253.2 & 300.2 & 316.2 \\
\hline Mean & 162.9 & 192.7 & 205.2 & 162.9 & 192.7 & 205.2 \\
\hline \multicolumn{7}{|l|}{$100 \%$ Stocks } \\
\hline 1 & 11.1 & 12.8 & 14.5 & 6.4 & 7.3 & 8.5 \\
\hline 10 & 151.4 & 179.9 & 190.1 & 79.9 & 94.3 & 102.4 \\
\hline 50 & 460.5 & 549.8 & 564.9 & 234.8 & 278.8 & 293.5 \\
\hline 90 & 1420.6 & 1704.9 & 1710.3 & 705.0 & 841.1 & 860.4 \\
\hline Mean & 677.7 & 812.0 & 821.8 & 339.9 & 404.8 & 418.6 \\
\hline \multicolumn{7}{|c|}{$(110-$ Age $) \%$ Stocks, $($ Age +10$) \%$ TIPS } \\
\hline 1 & 46.4 & 54.3 & 59.2 & 35.9 & 41.9 & 46.2 \\
\hline 10 & 150.5 & 178.1 & 189.2 & 115.9 & 137.0 & 146.9 \\
\hline 50 & 240.5 & 285.2 & 300.0 & 185.2 & 219.3 & 232.8 \\
\hline 90 & 380.9 & 452.3 & 471.7 & 293.3 & 347.7 & 365.6 \\
\hline Mean & 256.0 & 303.6 & 318.7 & 197.1 & 233.5 & 247.2 \\
\hline \multicolumn{7}{|c|}{$(110-$ Age $) \%$ Stocks, $($ Age +10$) \%$ Bonds } \\
\hline 1 & 32.2 & 38.0 & 42.1 & 25.2 & 29.6 & 33.1 \\
\hline 10 & 138.7 & 164.1 & 175.0 & 107.0 & 126.4 & 136.1 \\
\hline 50 & 253.7 & 301.0 & 316.1 & 195.1 & 231.2 & 244.9 \\
\hline 90 & 466.4 & 554.6 & 574.2 & 357.7 & 424.7 & 443.3 \\
\hline Mean & 284.2 & 337.4 & 352.6 & 218.4 & 258.9 & 272.8 \\
\hline \multicolumn{7}{|c|}{ Empirical Lifecycle, Stocks and TIPS } \\
\hline 1 & 55.1 & 64.3 & 72.0 & 40.5 & 47.1 & 53.4 \\
\hline 10 & 164.0 & 194.6 & 206.4 & 114.7 & 135.5 & 146.4 \\
\hline 50 & 299.8 & 357.2 & 369.9 & 204.4 & 242.4 & 255.5 \\
\hline 90 & 561.8 & 672.6 & 682.6 & 373.8 & 445.6 & 459.2 \\
\hline Mean & 339.5 & 405.3 & 416.8 & 229.5 & 272.7 & 285.1 \\
\hline \multicolumn{7}{|c|}{ Empirical Lifecycle, Stocks and Bonds } \\
\hline 1 & 31.9 & 37.3 & 41.9 & 23.6 & 27.6 & 31.5 \\
\hline 10 & 155.2 & 184.2 & 195.1 & 108.3 & 128.0 & 138.1 \\
\hline 50 & 311.6 & 371.3 & 384.3 & 212.1 & 251.7 & 265.1 \\
\hline 90 & 642.7 & 769.4 & 779.9 & 427.8 & 509.7 & 524.6 \\
\hline Mean & 367.0 & 438.2 & 449.7 & 247.5 & 294.3 & 307.0 \\
\hline \multicolumn{7}{|c|}{ Equivalent Fixed Proportion Stocks ( $53 \%$ baseline, $61.5 \%$ with reduced returns) } \\
\hline 1 & 30.8 & 35.9 & 40.1 & 18.8 & 21.8 & 25.0 \\
\hline 10 & 150.5 & 178.4 & 189.2 & 104.3 & 123.2 & 132.7 \\
\hline 50 & 294.7 & 350.6 & 364.9 & 215.5 & 255.7 & 269.5 \\
\hline 90 & 582.9 & 695.5 & 711.7 & 450.2 & 535.9 & 553.6 \\
\hline Mean & 340.0 & 404.9 & 418.6 & 254.5 & 302.4 & 316.0 \\
\hline \multicolumn{7}{|c|}{ Feldstein (2005) "No Lose" Plan } \\
\hline 1 & 96.6 & 113.8 & 124.3 & 95.3 & 112.2 & 122.7 \\
\hline 10 & 143.8 & 170.4 & 181.8 & 117.9 & 139.2 & 150.7 \\
\hline 50 & 260.4 & 310.7 & 320.6 & 172.7 & 204.8 & 216.6 \\
\hline 90 & 645.5 & 777.0 & 775.6 & 352.6 & 421.3 & 430.1 \\
\hline Mean & 350.6 & 420.3 & 426.8 & 214.8 & 255.6 & 266.2 \\
\hline
\end{tabular}

Source: Authors' tabulations of simulation results. See text for further details. 
Table 6: Certainty Equivalent Wealth (\$2000) For Different Asset Allocation Rules and Different Expected Stock Returns, No Other Wealth

\begin{tabular}{|c|c|c|c|c|c|c|}
\hline \multirow[b]{2}{*}{ Risk Aversion/Investment Strategy } & \multicolumn{3}{|c|}{ Empirical Stock Returns } & \multicolumn{3}{|c|}{$\begin{array}{l}\text { Empirical Stock Returns, Reduced } \\
300 \text { Basis Points }\end{array}$} \\
\hline & $\begin{array}{l}\text { Less Than } \\
\text { HS Degree }\end{array}$ & $\begin{array}{l}\text { HS and/or } \\
\text { Some } \\
\text { College }\end{array}$ & $\begin{array}{l}\text { College or } \\
\text { Post- } \\
\text { graduate }\end{array}$ & $\begin{array}{l}\text { Less Than } \\
\text { HS } \\
\text { Degree }\end{array}$ & $\begin{array}{l}\text { HS } \\
\text { and/or } \\
\text { Some } \\
\text { College }\end{array}$ & $\begin{array}{l}\text { College or } \\
\text { Post- } \\
\text { graduate }\end{array}$ \\
\hline \multicolumn{7}{|l|}{$\alpha=0$} \\
\hline $100 \%$ TIPS & 137.6 & 162.6 & 174.4 & & & \\
\hline 100\% Government Bonds & 162.9 & 192.7 & 205.2 & & & \\
\hline $100 \%$ Stocks & 677.7 & 812.0 & 821.8 & 339.9 & 404.8 & 418.6 \\
\hline$(110-$ Age $) \%$ Stocks, $($ Age +10$) \%$ TIPS & 256.0 & 303.6 & 318.7 & 197.1 & 233.5 & 247.2 \\
\hline$(110-$ Age $) \%$ Stocks, $($ Age +10$) \%$ Bonds & 284.2 & 337.4 & 352.6 & 218.4 & 258.9 & 272.8 \\
\hline Empirical Lifecycle, Stocks and TIPS & 339.6 & 405.3 & 416.8 & 229.5 & 272.7 & 285.2 \\
\hline Empirical Lifecycle, Stocks and Bonds & 367.0 & 438.2 & 449.7 & 247.5 & 294.3 & 307.0 \\
\hline Equivalent Fixed Proportion Stocks & 340.0 & 404.9 & 418.6 & 254.5 & 302.4 & 316.0 \\
\hline "No Lose" Plan & 350.6 & 420.3 & 426.8 & 214.8 & 255.6 & 266.2 \\
\hline \multicolumn{7}{|l|}{$\alpha=1$} \\
\hline $100 \%$ TIPS & 137.6 & 162.6 & 174.4 & & & \\
\hline $100 \%$ Government Bonds & 149.7 & 177.1 & 189.4 & & & \\
\hline $100 \%$ Stocks & 461.8 & 551.4 & 567.1 & 235.8 & 279.9 & 294.8 \\
\hline$(110-$ Age $) \%$ Stocks, $($ Age +10$) \%$ TIPS & 239.8 & 284.3 & 299.2 & 184.7 & 218.6 & 232.1 \\
\hline$(110-$ Age $) \%$ Stocks, $($ Age +10$) \%$ Bonds & 253.9 & 301.3 & 316.5 & 195.4 & 231.4 & 245.2 \\
\hline Empirical Lifecycle, Stocks and TIPS & 301.9 & 359.7 & 372.7 & 205.8 & 244.2 & 257.4 \\
\hline Empirical Lifecycle, Stocks and Bonds & 313.9 & 374.0 & 387.3 & 213.8 & 253.7 & 267.2 \\
\hline Equivalent Fixed Proportion Stocks & 295.4 & 351.4 & 365.8 & 216.0 & 256.2 & 270.1 \\
\hline "No Lose" Plan & 285.1 & 340.4 & 351.0 & 190.1 & 225.6 & 237.7 \\
\hline \multicolumn{7}{|l|}{$\alpha=2$} \\
\hline $100 \%$ TIPS & 137.6 & 162.6 & 174.4 & & & \\
\hline $100 \%$ Government Bonds & 138.2 & 163.3 & 175.5 & & & \\
\hline $100 \%$ Stocks & 316.5 & 376.5 & 394.1 & 164.9 & 194.9 & 209.3 \\
\hline$(110-$ Age $) \%$ Stocks, $($ Age +10$) \%$ TIPS & 224.5 & 266.1 & 280.6 & 172.9 & 204.6 & 217.8 \\
\hline$(110-$ Age $) \%$ Stocks, $($ Age +10$) \%$ Bonds & 227.1 & 269.2 & 284.2 & 174.9 & 207.0 & 220.5 \\
\hline Empirical Lifecycle, Stocks and TIPS & 269.3 & 320.4 & 334.5 & 185.2 & 219.5 & 233.1 \\
\hline Empirical Lifecycle, Stocks and Bonds & 269.7 & 320.8 & 335.2 & 185.5 & 219.7 & 233.6 \\
\hline Equivalent Fixed Proportion Stocks & 257.1 & 305.4 & 320.3 & 183.7 & 217.5 & 231.3 \\
\hline "No Lose" Plan & 245.2 & 291.9 & 304.6 & 174.5 & 206.8 & 219.6 \\
\hline \multicolumn{7}{|l|}{$\alpha=4$} \\
\hline $100 \%$ TIPS & 137.6 & 162.6 & 174.4 & & & \\
\hline $100 \%$ Government Bonds & 119.1 & 140.5 & 152.3 & & & \\
\hline $100 \%$ Stocks & 154.0 & 181.5 & 197.0 & 83.5 & 97.6 & 108.8 \\
\hline$(110-$ Age $) \%$ Stocks, $($ Age +10$) \%$ TIPS & 196.4 & 232.6 & 246.6 & 151.3 & 178.9 & 191.4 \\
\hline$(110-$ Age $) \%$ Stocks, $($ Age +10$) \%$ Bonds & 182.2 & 215.5 & 229.9 & 140.6 & 166.0 & 178.8 \\
\hline Empirical Lifecycle, Stocks and TIPS & 216.6 & 256.9 & 272.3 & 151.5 & 179.0 & 193.0 \\
\hline Empirical Lifecycle, Stocks and Bonds & 202.3 & 239.8 & 255.1 & 141.8 & 167.4 & 181.2 \\
\hline Equivalent Fixed Proportion Stocks & 196.0 & 232.1 & 247.0 & 133.9 & 157.9 & 171.0 \\
\hline "No Lose" Plan & 201.7 & 239.3 & 253.4 & 156.2 & 184.7 & 197.9 \\
\hline
\end{tabular}

Source: Authors' tabulations from simulation analysis. See text for further discussion. 
Table 7: Certainty Equivalent Wealth (\$2000) For Different Asset Allocation Rules and Different Expected Stock Returns, Other Wealth Equal to Other Financial Wealth in HRS

\begin{tabular}{|c|c|c|c|c|c|c|}
\hline \multirow[b]{2}{*}{ Risk Aversion/Investment Strategy } & \multicolumn{3}{|c|}{ Empirical Stock Returns } & \multicolumn{3}{|c|}{$\begin{array}{l}\text { Empirical Stock Returns, Reduced } \\
300 \text { Basis Points }\end{array}$} \\
\hline & $\begin{array}{l}\text { Less Than } \\
\text { HS Degree }\end{array}$ & $\begin{array}{l}\text { HS and/or } \\
\text { Some } \\
\text { College }\end{array}$ & $\begin{array}{l}\text { College or } \\
\text { Post- } \\
\text { graduate }\end{array}$ & $\begin{array}{l}\text { Less Than } \\
\text { HS } \\
\text { Degree }\end{array}$ & $\begin{array}{l}\text { HS and/or } \\
\text { Some } \\
\text { College }\end{array}$ & $\begin{array}{l}\text { College or } \\
\text { Post- } \\
\text { graduate }\end{array}$ \\
\hline \multicolumn{7}{|l|}{$\alpha=0$} \\
\hline $100 \%$ TIPS & 137.6 & 162.6 & 174.4 & & & \\
\hline $100 \%$ Government Bonds & 162.9 & 192.7 & 205.2 & & & \\
\hline $100 \%$ Stocks & 677.7 & 812.0 & 821.8 & 339.9 & 404.8 & 418.6 \\
\hline$(110-$ Age $) \%$ Stocks, $($ Age +10$) \%$ TIPS & 256.0 & 303.6 & 318.7 & 197.1 & 233.5 & 247.2 \\
\hline$(110-$ Age $) \%$ Stocks, $($ Age +10$) \%$ Bonds & 284.2 & 337.4 & 352.6 & 218.4 & 258.9 & 272.8 \\
\hline Empirical Lifecycle, Stocks and TIPS & 339.6 & 405.3 & 416.8 & 229.5 & 272.7 & 285.2 \\
\hline Empirical Lifecycle, Stocks and Bonds & 367.0 & 438.2 & 449.7 & 247.5 & 294.3 & 307.0 \\
\hline Equivalent Fixed Proportion Stocks & 340.0 & 404.9 & 418.6 & 254.5 & 302.4 & 316.0 \\
\hline "No Lose" Plan & 350.6 & 420.3 & 426.8 & 214.8 & 255.6 & 266.2 \\
\hline \multicolumn{7}{|l|}{$\alpha=1$} \\
\hline $100 \%$ TIPS & 137.6 & 162.6 & 174.4 & & & \\
\hline $100 \%$ Government Bonds & 156.9 & 185.5 & 198.1 & & & \\
\hline $100 \%$ Stocks & 518.1 & 618.4 & 636.5 & 275.6 & 326.9 & 343.3 \\
\hline$(110-$ Age $) \%$ Stocks, $($ Age +10$) \%$ TIPS & 247.2 & 293.1 & 308.3 & 191.1 & 226.2 & 240.0 \\
\hline$(110-$ Age $) \%$ Stocks, $($ Age +10$) \%$ Bonds & 266.9 & 316.6 & 332.4 & 206.6 & 244.7 & 258.9 \\
\hline Empirical Lifecycle, Stocks and TIPS & 316.4 & 377.1 & 390.2 & 217.0 & 257.5 & 270.7 \\
\hline Empirical Lifecycle, Stocks and Bonds & 333.4 & 397.4 & 411.1 & 229.1 & 271.8 & 285.6 \\
\hline Equivalent Fixed Proportion Stocks & 312.8 & 371.9 & 387.0 & 233.4 & 276.8 & 291.2 \\
\hline "No Lose" Plan & 306.1 & 365.6 & 376.2 & 200.3 & 237.8 & 249.7 \\
\hline \multicolumn{7}{|l|}{$\alpha=2$} \\
\hline $100 \%$ TIPS & 137.6 & 162.6 & 174.4 & & & \\
\hline $100 \%$ Government Bonds & 151.7 & 179.1 & 191.8 & & & \\
\hline $100 \%$ Stocks & 416.5 & 495.4 & 517.1 & 233.1 & 275.6 & 292.9 \\
\hline$(110-$ Age $) \%$ Stocks, $($ Age +10$) \%$ TIPS & 239.1 & 283.3 & 298.6 & 185.6 & 219.5 & 233.3 \\
\hline$(110-$ Age $) \%$ Stocks, $($ Age +10$) \%$ Bonds & 252.0 & 298.5 & 314.6 & 196.3 & 232.2 & 246.6 \\
\hline Empirical Lifecycle, Stocks and TIPS & 296.7 & 353.0 & 367.4 & 206.2 & 244.3 & 258.1 \\
\hline Empirical Lifecycle, Stocks and Bonds & 306.2 & 364.2 & 379.4 & 213.8 & 253.3 & 267.6 \\
\hline Equivalent Fixed Proportion Stocks & 290.0 & 344.3 & 360.3 & 216.0 & 255.7 & 270.6 \\
\hline "No Lose" Plan & 277.0 & 330.0 & 342.8 & 190.0 & 225.3 & 238.0 \\
\hline \multicolumn{7}{|l|}{$\alpha=4$} \\
\hline $100 \%$ TIPS & 137.6 & 162.6 & 174.4 & & & \\
\hline $100 \%$ Government Bonds & 142.6 & 168.2 & 180.9 & & & \\
\hline $100 \%$ Stocks & 301.2 & 356.3 & 379.2 & 181.5 & 213.6 & 230.6 \\
\hline$(110-$ Age $) \%$ Stocks, $($ Age +10$) \%$ TIPS & 224.5 & 265.6 & 281.1 & 175.5 & 207.3 & 221.1 \\
\hline$(110-$ Age $) \%$ Stocks, $($ Age +10$) \%$ Bonds & 227.2 & 268.7 & 285.1 & 179.1 & 211.4 & 226.0 \\
\hline Empirical Lifecycle, Stocks and TIPS & 265.0 & 314.5 & 330.6 & 188.4 & 222.7 & 237.2 \\
\hline Empirical Lifecycle, Stocks and Bonds & 264.8 & 314.0 & 330.8 & 189.9 & 224.4 & 239.4 \\
\hline Equivalent Fixed Proportion Stocks & 254.1 & 300.9 & 317.8 & 189.2 & 223.3 & 238.6 \\
\hline "No Lose" Plan & 241.1 & 286.4 & 301.2 & 176.1 & 208.5 & 221.9 \\
\hline
\end{tabular}


Table 8: Certainty Equivalent Wealth (\$2000) For Different Asset Allocation Rules and Different Expected Stock Returns, Other Wealth Equal to All HRS Non-Retirement Plan Wealth

\begin{tabular}{|c|c|c|c|c|c|c|}
\hline \multirow[b]{2}{*}{ Risk Aversion/Investment Strategy } & \multicolumn{3}{|c|}{ Empirical Stock Returns } & \multicolumn{3}{|c|}{$\begin{array}{l}\text { Empirical Stock Returns, Reduced } \\
300 \text { Basis Points }\end{array}$} \\
\hline & $\begin{array}{l}\text { Less Than } \\
\text { HS } \\
\text { Degree }\end{array}$ & $\begin{array}{l}\text { HS and/or } \\
\text { Some } \\
\text { College }\end{array}$ & $\begin{array}{l}\text { College or } \\
\text { Post- } \\
\text { graduate }\end{array}$ & $\begin{array}{l}\text { Less Than } \\
\text { HS } \\
\text { Degree }\end{array}$ & $\begin{array}{l}\text { HS and/or } \\
\text { Some } \\
\text { College }\end{array}$ & $\begin{array}{l}\text { College or } \\
\text { Post- } \\
\text { graduate }\end{array}$ \\
\hline \multicolumn{7}{|l|}{$\alpha=0$} \\
\hline $100 \%$ TIPS & 137.8 & 164.9 & 178.0 & & & \\
\hline $100 \%$ Government Bonds & 163.0 & 194.9 & 208.6 & & & \\
\hline $100 \%$ Stocks & 677.8 & 812.3 & 817.5 & 340.0 & 406.3 & 418.9 \\
\hline$(110-$ Age $) \%$ Stocks, $($ Age +10$) \%$ TIPS & 256.1 & 305.5 & 321.4 & 197.3 & 235.6 & 250.4 \\
\hline$(110-$ Age $) \%$ Stocks, $($ Age +10$) \%$ Bonds & 284.3 & 339.2 & 355.1 & 218.5 & 260.9 & 275.8 \\
\hline Empirical Lifecycle, Stocks and TIPS & 339.7 & 406.9 & 418.7 & 229.7 & 274.7 & 288.0 \\
\hline Empirical Lifecycle, Stocks and Bonds & 367.1 & 439.7 & 451.4 & 247.7 & 296.2 & 309.7 \\
\hline Equivalent Fixed Proportion Stocks & 340.1 & 406.4 & 420.6 & 254.7 & 304.3 & 318.7 \\
\hline "No Lose" Plan & 350.7 & 421.8 & 428.4 & 214.9 & 257.6 & 269.1 \\
\hline \multicolumn{7}{|l|}{$\alpha=1$} \\
\hline $100 \%$ TIPS & 137.8 & 164.9 & 178.0 & & & \\
\hline $100 \%$ Government Bonds & 158.3 & 189.9 & 204.4 & & & \\
\hline $100 \%$ Stocks & 534.1 & 647.6 & 677.0 & 284.5 & 344.3 & 366.8 \\
\hline$(110-$ Age $) \%$ Stocks, $($ Age +10$) \%$ TIPS & 248.9 & 297.7 & 314.9 & 192.5 & 230.4 & 246.0 \\
\hline$(110-$ Age $) \%$ Stocks, $($ Age +10$) \%$ Bonds & 269.9 & 323.5 & 341.9 & 208.9 & 250.5 & 267.1 \\
\hline Empirical Lifecycle, Stocks and TIPS & 320.1 & 385.0 & 400.9 & 219.4 & 263.5 & 278.9 \\
\hline Empirical Lifecycle, Stocks and Bonds & 338.4 & 407.6 & 425.0 & 232.4 & 279.4 & 296.0 \\
\hline Equivalent Fixed Proportion Stocks & 317.0 & 380.9 & 399.4 & 237.1 & 285.0 & 302.7 \\
\hline "No Lose" Plan & 311.9 & 377.4 & 392.4 & 202.7 & 244.0 & 258.2 \\
\hline \multicolumn{7}{|l|}{$\alpha=2$} \\
\hline $100 \%$ TIPS & 137.8 & 164.9 & 178.0 & & & \\
\hline $100 \%$ Government Bonds & 154.0 & 185.3 & 200.5 & & & \\
\hline $100 \%$ Stocks & 441.7 & 541.3 & 583.5 & 247.0 & 302.1 & 330.1 \\
\hline$(110-$ Age $) \%$ Stocks, $($ Age +10$) \%$ TIPS & 242.2 & 290.4 & 308.7 & 188.0 & 225.6 & 241.9 \\
\hline$(110-$ Age $) \%$ Stocks, $($ Age +10$) \%$ Bonds & 257.3 & 309.7 & 330.2 & 200.4 & 241.3 & 259.3 \\
\hline Empirical Lifecycle, Stocks and TIPS & 303.2 & 366.1 & 385.3 & 210.4 & 253.6 & 270.8 \\
\hline Empirical Lifecycle, Stocks and Bonds & 314.8 & 381.1 & 402.8 & 219.5 & 265.2 & 284.1 \\
\hline Equivalent Fixed Proportion Stocks & 297.5 & 359.2 & 381.0 & 222.5 & 268.9 & 289.0 \\
\hline "No Lose" Plan & 285.7 & 347.3 & 367.0 & 193.8 & 233.9 & 249.9 \\
\hline \multicolumn{7}{|l|}{$\alpha=4$} \\
\hline $100 \%$ TIPS & 137.8 & 164.9 & 178.0 & & & \\
\hline $100 \%$ Government Bonds & 146.6 & 177.3 & 193.7 & & & \\
\hline $100 \%$ Stocks & 333.7 & 415.8 & 468.1 & 199.9 & 248.2 & 281.0 \\
\hline$(110-$ Age $) \%$ Stocks, $($ Age +10$) \%$ TIPS & 230.1 & 277.2 & 297.4 & 179.8 & 216.8 & 234.3 \\
\hline$(110-$ Age $) \%$ Stocks, $($ Age +10$) \%$ Bonds & 236.3 & 286.4 & 310.1 & 186.0 & 225.6 & 245.7 \\
\hline Empirical Lifecycle, Stocks and TIPS & 275.7 & 335.3 & 359.3 & 195.4 & 237.1 & 256.9 \\
\hline Empirical Lifecycle, Stocks and Bonds & 278.5 & 340.1 & 367.5 & 199.0 & 242.5 & 264.6 \\
\hline Equivalent Fixed Proportion Stocks & 266.4 & 324.4 & 350.9 & 199.4 & 243.4 & 266.4 \\
\hline "No Lose" Plan & 252.3 & 308.3 & 332.9 & 181.3 & 219.6 & 237.7 \\
\hline
\end{tabular}


Figure 1: Aggregate Net Assets of Target-Year Lifecycle Funds, March 1994-March 2005

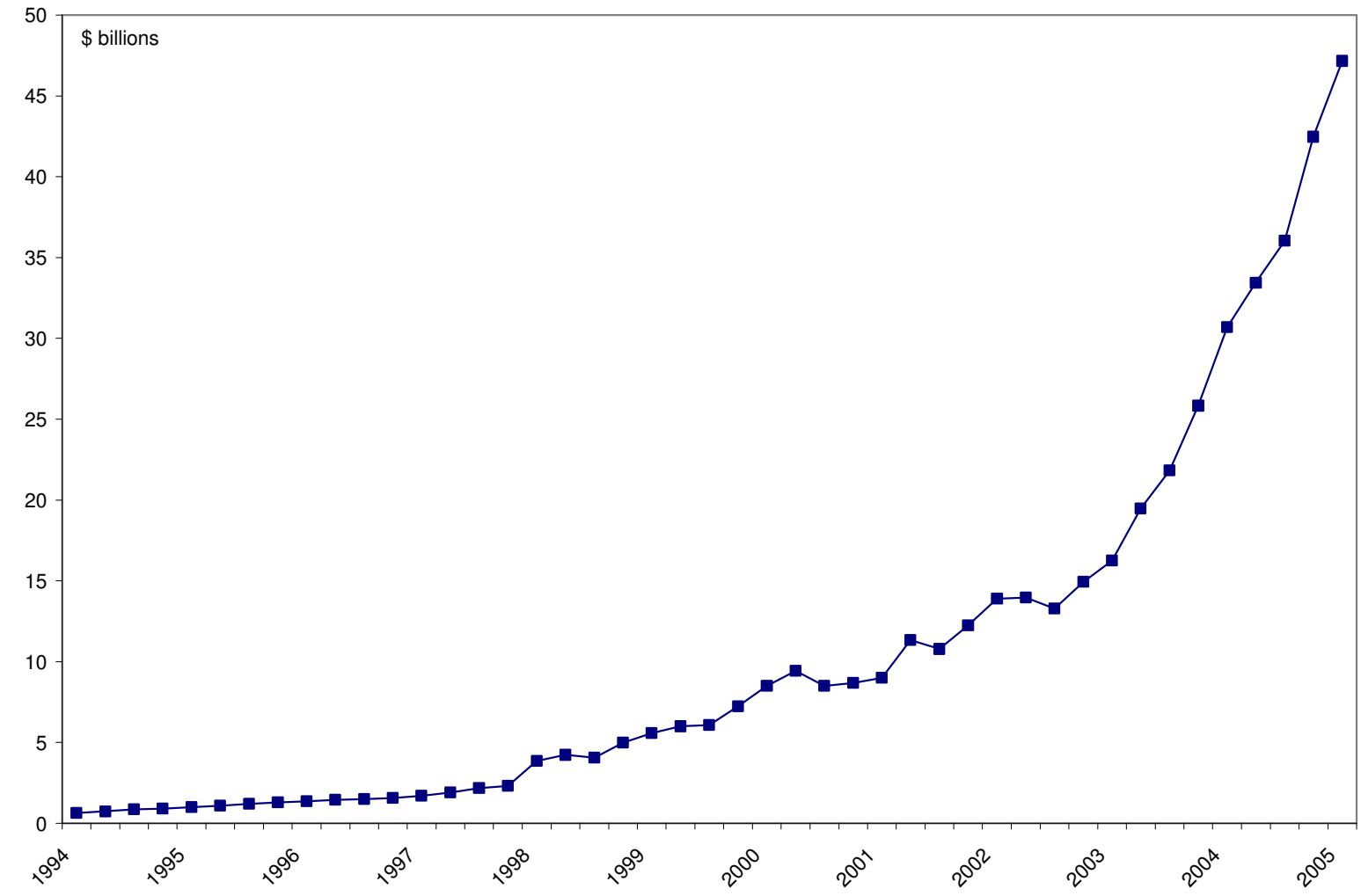

This figure shows quarterly net assets of all mutual funds categorized by Morningstar as retirement or lifecycle funds which also have a target-year rebalancing feature. As of March 2005, the $\$ 47.1$ billion represents assets in the following families: Barclays Global Investors LifePath, Fidelity Freedom Funds, Fidelity Advisor Freedom, Intrust Bank NestEgg, MassMutual Select Destination Retire, Principal Investors Lifetime, Putnam Retirement Ready, Scudder Target, State Farm Lifepath, TIAA-CREF Institutional Lifecycle, T. Rowe Price Retirement, Vanguard Target Retirement, Vantagepoint Milestone, and Wells Fargo Outlook. Net assets for lifecycle funds were assembled from fund reports and data provided by Morningstar. 
Figure 2: Median Household Wage Income in the HRS

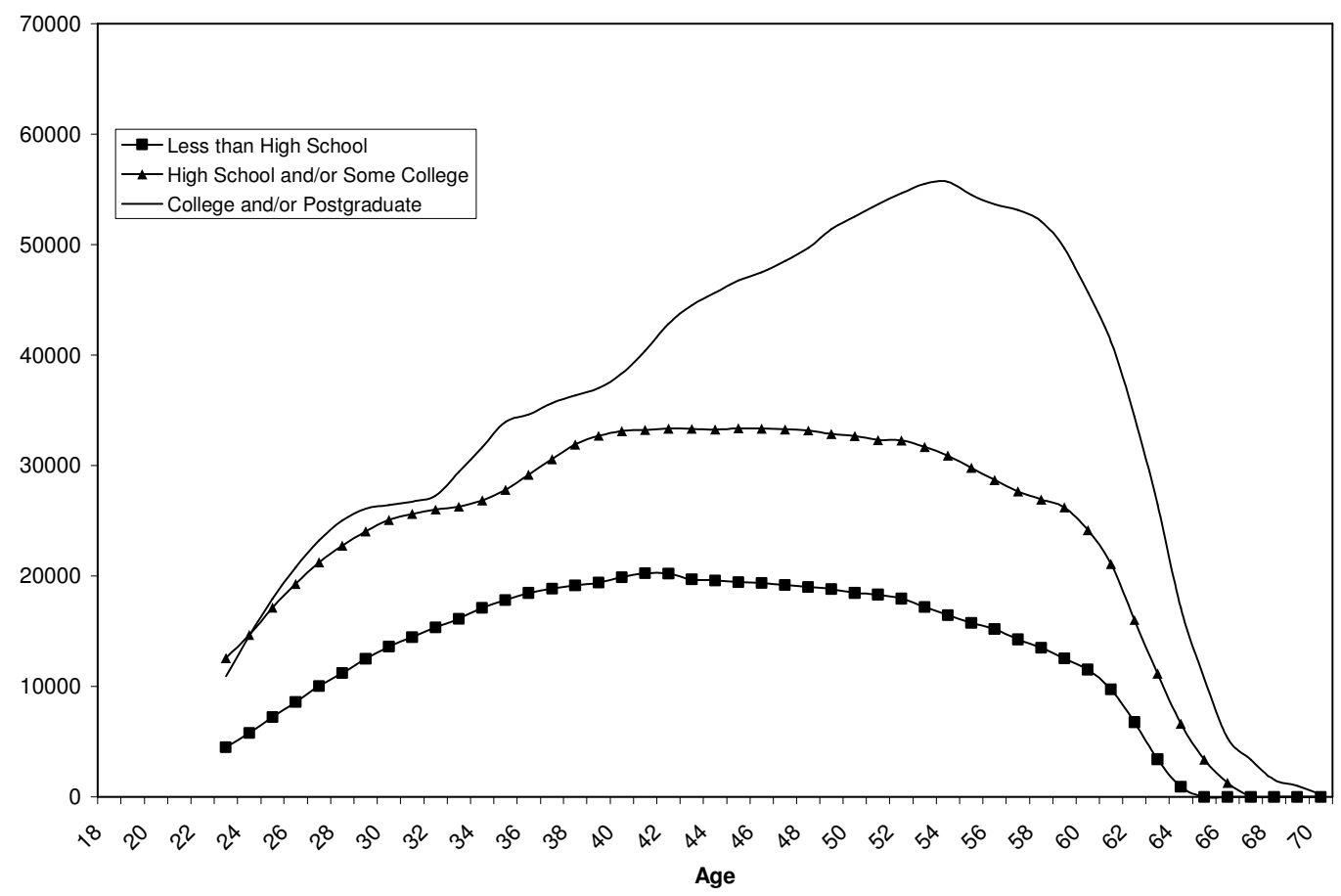

Source: Authors' calculations from social security earnings histories of HRS respondents.

Figure 3: Median Household Wage Income in the HRS for Couples with Male Aged 59-72

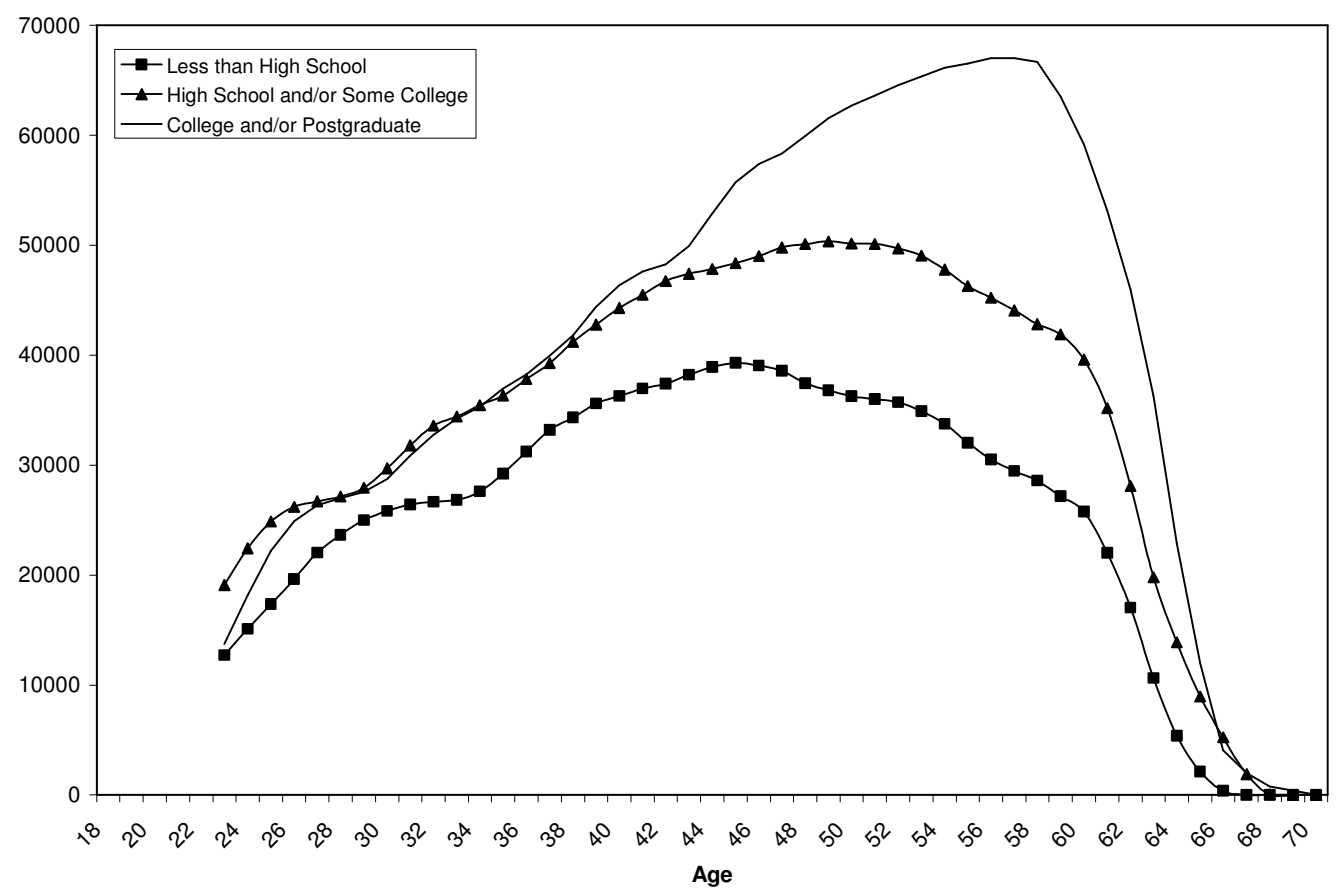

Source: Authors' calculations from social security earnings histories of HRS respondents. 
Figure 4: Median Household Wage Income in the HRS for Couples with Male Aged 63-72

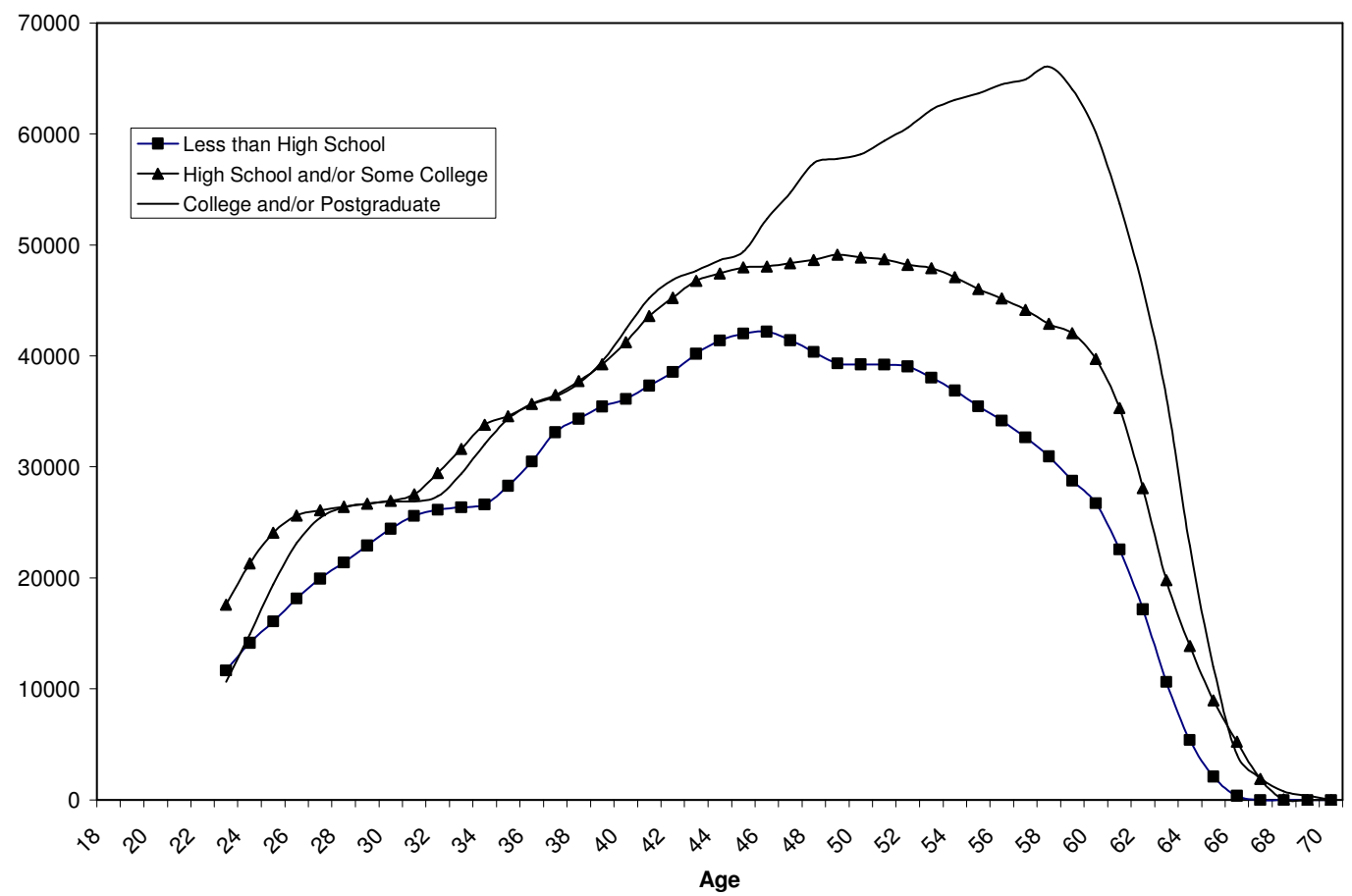

Source: Authors' calculations from social security earnings histories of HRS respondents. 